\author{
JERZY DYGDAŁA \\ https://orcid.org/0000-0002-9804-6845 \\ Instytut Historii PAN, Toruń
}

\title{
LWOWSKA WYPRAWA KRÓLA STANISŁAWA LESZCZYŃSKIEGO W 1709 ROKU (CZY ZAMIERZANO IŚĆ NA POMOC KAROLOWI XII NA UKRAINĘ?)
}

\begin{abstract}
Abstrakt: Artykuł omawia szerzej nieznany epizod pobytu króla Stanisława Leszczyńskiego we Lwowie w 1709 r. Wiązał się on z wydarzeniami wielkiej wojny północnej i próbą przyjścia z pomocą szwedzkiemu królowi Karolowi XII, prowadzącemu wówczas wojnę z Rosją. Siły króla Stanisława i wspomagającego go korpusu szwedzkiego okazały się za słabe, by wypełnić to zadanie. Zresztą dowódcy szwedzcy zdawali sobie $z$ tego sprawę i wyraźnie opóźniali marsz swych oddziałów w kierunku Ukrainy.
\end{abstract}

Słowa kluczowe: wielka wojna północna, król Stanisław Leszczyński, Lwów, malarz Jerzy Eleuter Siemiginowski.
Abstract: The article discusses a practically unknown episode of King Stanisław Leszczyński's visit to Lviv in 1709 . The visit was related to the course of the Great Northern War and an attempt to help King Charles XII of Sweden, who at that time was waging war with Russia. However, the forces of King Stanisław and the supporting Swedish corps were too weak to fulfil the task. In any case, the Swedish commanders were aware of the fact and deliberately delayed the moving of their troops towards Ukraine.

Keywords: Great Northern War, King Stanisław Leszczyński, Lviv, painter Jerzy Eleuter Siemiginowski.

Krótki pobyt króla Stanisława Leszczyńskiego we Lwowie w kwietniu 1709 r. nie został odnotowany w pracach poświęconych dziejom tego miasta w czasach wielkiej wojny północnej. Obszernie pisano natomiast o wcześniejszej wizycie tego monarchy w dniach 15-24 września 1704 r., kiedy to towarzyszył on zdobywcy Lwowa, królowi szwedzkiemu 
Karolowi XII ${ }^{1}$. Jest to o tyle dziwne, że już w 1829 r. autor najobszerniejszej wówczas pracy o dziejach Lwowa, karmelita Ignacy Chodyniecki, podał, iż król Stanisław po raz drugi zawitał do Lwowa w 1709 r. wraz z wojskiem koronnym dowodzonym przez wojewodę kijowskiego Józefa Potockiego. Za nimi miały wkroczyć do miasta oddziały szwedzkie gen. Krassau (Ernst Detlof von Krassow / Krassaw), który nałożył na mieszczan wysoką kontrybucję, jednak na wiadomość o pojawieniu się na Podolu wojsk rosyjskich, wspierających siły hetmana Adama Mikołaja Sieniawskiego, Leszczyński i Szwedzi wycofali się ze Lwowa, udając się do Wielkopolski²

Sprawa drugiej wizyty króla Stanisława we Lwowie została też pominięta w starszych opracowaniach, poświęconych przebiegowi wielkiej wojny północnej na ziemiach Rzeczypospolitej w latach 1708-1709. Józef Feldman zamieścił tylko krótką wzmiankę, że król Stanisław „tak długo manewrował w okolicy Lwowa, aż [hetman Adam Mikołaj - J.D.] Sieniawski w marcu [1709] wycofał się bezpiecznie na Podole”. W późniejszej biografii Stanisława Leszczyńskiego tenże autor w ogóle nie wspomniał o marszu monarchy w stronę Lwowa w 1708 i 1709 r. ${ }^{3}$ W najobszerniejszej polskiej monografii dotyczącej organizacji wojska i przebiegu działań militarnych na obszarze Rzeczypospolitej w czasie wielkiej wojny północnej, pióra Jana Wimmera, znajdujemy błędną informację o wycofaniu się króla Stanisława i towarzyszących mu wojsk szwedzkich z początkiem 1709 r. z Podlasia do Wielkopolski i o wymarszu tych oddziałów dopiero w marcu tego roku w kierunku Małopolski. Pod koniec tegoż miesiąca Szwedzi mieli zająć Lwów, nie wspomniano jednak o pobycie w tym mieście Leszczyńskiego. Podano tylko, iż dopiero po 23 maja 1709 r. siły „rozpoczęły odwrót na zachód”4. Informacje te powtórzył w skrócie Edmund Cieślak w swej biografii króla Stanisława, stwierdzając, iż z początkiem listopada 1708 r. monarcha ten wraz z szwedzkim

${ }^{1}$ F. Jaworski, Królowie polscy we Lwowie, Lwów 1912, s. 122-126; B. Popiołek, Lwów w czasach Augusta II, w: Lwów. Miasto, społeczeństwo, kultura. Studia z dziejów Lwowa, t. 4, red. K. Karolczak, Kraków 2002, s. 95-96. Zob. też szczegółowe informacje podane przez ówczesnego lwowskiego kanonika i kronikarza Jana Tomasza Józefowicza, Lwów utrapiony in anno 1704 albo Dyjaryjusz wziętego Lwowa przez króla szwedzkiego Karola XII die 6 mensis Septembris anno 1704, wyd. P. Borek, Kraków 2003, s. 137-174.

2 I. Chodyniecki, Historja stołecznego Królestw Galicyi i Lodomerii miasta Lwowa, Lwów 1865 [wyd. 2], s. 269-270.

3 J. Feldman, Polska $w$ dobie wielkiej wojny pótnocnej 1704-1709, Kraków 1925, s. 307; idem, Stanisław Leszczyński, Warszawa 1984.

${ }^{4}$ J. Wimmer, Wojsko Rzeczypospolitej $w$ dobie wojny północnej (1700-1717), Warszawa 1956, s. 336, 338-339. O rzekomym wycofaniu się króla Stanisława wiosną 1709 r. z Mazowsza do Poznania jako pierwszy pisał Kazimierz Jarochowski, Stanisław Leszczyński po Pultawie, w: idem, Opowiadania i studia historyczne, serya nowa, Poznań 1884, s. 249. 
korpusem gen. Krassowa wyruszył w kierunku Podlasia, po klęsce swych sił w bitwie pod Koniecpolem (21 XI 1708) cofnął się jednak do Wielkopolski, skąd wymaszerował dopiero w marcu 1709 r. i dotarł wraz z oddziałami szwedzkimi do Lwowa. Po informacji o zbliżaniu się sił rosyjskich „wojska Leszczyńskiego i szwedzkie wycofały się na zachód”. Natomiast Józef Andrzej Gierowski, przedstawiając marsz wojsk szwedzkich i króla Stanisława z Prus Królewskich aż do województwa ruskiego w 1708-1709 r., nie popełnił błędu dotyczącego rzekomego wycofania się tych sił do Wielkopolski. Wspomniał wprawdzie tylko jednym zdaniem, iż „Stanisław podczas swego pobytu we Lwowie w połowie kwietnia [1709] podjął przygotowania do natarcia przeciwko armii Sieniawskiego, które otworzyłyby mu drogę na Ukrainę", zwrócił jednak uwagę na fakt, iż oddziały wojewody kijowskiego Józefa Potockiego, przy bierności Szwedów, podeszły na wschód od Lwowa aż pod Brzeżany, ale nie odniosły sukcesu. Dodał też, że na wiadomość z początku maja 1709 r. o zbliżaniu się oddziałów rosyjskich wysłanych z Kijowa na pomoc hetmanowi Sieniawskiemu, gen. Krassow zdecydował się na odwrót ${ }^{6}$. Niedawno Adam Perłakowski, opierając się na niepewnych i bałamutnych doniesieniach jednego z regimentarzy wojsk koronnych, stwierdził, iż „Stanisław Leszczyński ostatecznie do Lwowa nie dotarł", odnosząc to do sytuacji z drugiej połowy marca 1709 r. Zwrócił jednak uwagę, że z nieco późniejszych informacji tegoż regimentarza z 17 kwietnia wynikałoby, iż król Stanisław i szwedzki gen. Krassow opuścili Lwów, kierując się w stronę Brzeżan, głównej twierdzy hetmana wielkiego koronnego Sieniawskiego ${ }^{7}$.

W tej sytuacji warto szerzej przedstawić okoliczności powolnego marszu szwedzkiego korpusu gen. Krassowa w kierunku Lwowa i pobytu w tym mieście króla Stanisława, zakończonego nieoczekiwanym powrotem w okolice Jarosławia. Podstawę źródłową niniejszego artykułu stanowią przede wszystkim listy Jozafata Michała Karpia (późniejszego biskupa żmudzkiego), ówczesnego sekretarza króla Stanisława, do kanclerza wielkiego litewskiego Karola Stanisława Radziwiłła (Karp zaliczał się do wiernych klientów radziwiłłowskich). Listy te, pisane w formie diariusza, niezwykle szczegółowo, dzień po dniu przedstawiają czynności monarchy ${ }^{8}$.

${ }^{5}$ E. Cieślak, Stanisław Leszczyński, Wrocław 1994, s. 60.

${ }^{6}$ J.A. Gierowski, W cieniu Ligi Północnej, Wrocław 1971, s. 75.

${ }^{7}$ A. Perłakowski, Plotki, sprzeczne informacje i gra pozorów. Działalność Stanisława Krosnowskiego, regimentarza Adama Mikołaja Sieniawskiego, hetmana wielkiego koronnego w latach 1707-1709, w: Historia na źródłach oparta. Studia ofiarowane Profesorowi Tadeuszowi Srogoszowi w 65. rocznicę urodzin, red. A. Stroynowski, Częstochowa 2017, s. 269-270.

${ }^{8}$ Przy boku króla Stanisława Leszczyńskiego (1706-1709), t. 1: Wyprawy do Saksonii i Litwy w latach 1706-1708. Listy królewskich sekretarzy Samuela Kazimierza Szwykowskiego i Jozafata 


\section{W drodze do Lwowa}

Karol XII po narzuceniu Augustowi II traktatu w Altranstädt (24 IX 1706) i zmuszeniu go do rezygnacji z polskiej korony, przez dłuższy czas okupował Saksonię. Towarzyszył mu tam król Stanisław Leszczyński, mieszkający z niezbyt liczną świtą na zamku Mildenstein w niewielkim mieście Leisnig w pobliżu Lipska9 . Szwedzi przebywali w Saksonii aż do końca sierpnia 1707 r. Potem armia szwedzka przez cesarski śląsk, Wielkopolskę, Kujawy i Mazowsze skierowała się w stronę Litwy. Karol XII zamierzał wyprzeć wojska rosyjskie z Rzeczypospolitej, wkroczyć w granice Rosji i zmusić cara Piotra I do zawarcia pokoju. Według pierwotnej koncepcji króla szwedzkiego w tym marszu na Moskwę miał mu towarzyszyć król Stanisław i część wojsk litewskich, pod komendą nowego hetmana wielkiego, Jana Kazimierza Sapiehy. Tymczasem Rosjanie, nie decydując się na stoczenie walnej bitwy, stopniowo wycofywali się na wschód. Na przełomie 1707/1708 r. Szwedzi przekroczyli pod Włocławkiem Wisłę, dochodząc z końcem stycznia do Niemna. Zajęli potem znaczną część Wielkiego Księstwa Litewskiego i w połowie lutego 1708 r. Karol XII stanął w Smorgoniach, przenosząc miesiąc później swą kwaterę do Radoszkowicz na północ od Mińska. Zatrzymał się tam aż do początku czerwca $1708 \mathrm{r}^{10}$

Król Stanisław Leszczyński, podobnie jak Karol XII, udał się do Wielkopolski i na Kujawy, po czym z początkiem stycznia 1708 r. w ślad za wojskami szwedzkimi ruszył spod Torunia do Wielkiego Księstwa Litewskiego. W połowie lutego był w Grodnie, następnie prawie przez miesiąc przebywał w Gieranonach na północ od Lidy. Stamtąd pojechał do Wilna, gdzie gościł w dniach 22-29 marca. Zwiedzał miasto, które bardzo mu się podobało. Potem aż do połowy czerwca rezydował w Sołach na wschód od Wilna w pobliżu Smorgoń, czekając na decyzje - by nie powiedzieć rozkazy - szwedzkiego monarchy ${ }^{11}$. Tak król Stanisław, jak

Michała Karpia oraz fragmenty z gazet pisanych i diariuszy, wyd. J. Dygdała, Warszawa 2018; t. 2: W wędrówkach po Polsce między Gdańskiem a Lwowem w latach 1708-1709. Listy królewskiego sekretarza Jozafata Michała Karpia oraz fragmenty z gazet pisanych i diariuszy, wyd. J. Dygdała, Warszawa 2019.

9 Zob. J. Dygdała, Leszczyński w Saksonii, „Mówią Wieki” 2008, 11, s. 41-44.

10 B. Liljegren, Karol XII, Gdańsk 2015 (oryg. szw. 2000), s. 154-156; J.D. Hultman, O panowaniu Karola XII króla Szwecji, wyd. i przetłum. W. Krawczuk, Kraków 2015 (oryg. szW. 1819), s. 24-30, 111-122.

11 J. Dygdała, Z Torunia do Wilna podróż króla Stanisława zima 1708 roku, ZH 82, 2017, 2, s. 85-99; idem, Wizyta króla Stanisława Leszczyńskiego w Wilnie $w$ dniach 22-29 marca 1708 roku, w: Inter Regnum et Ducatum. Studia ofiarowane Profesorowi Janowi Tegowskiemu $w$ siedemdziesiąta rocznice urodzin, red. P. Guzowski, M. Liedke, K. Boroda, Białystok 2018, s. $119-131$. 
i większość osób z jego otoczenia, nie mieli najmniejszej ochoty towarzyszyć Karolowi XII w wyprawie na Moskwę. Kilkakrotnie Leszczyński sugerował szwedzkiemu władcy, że najlepiej byłoby, gdyby mógł powrócić do Polski i tam zabiegać o pacyfikację wewnętrzną kraju. Nie wywoływało to jednak żadnej reakcji ze strony Karola XII. Dopiero 23 maja 1708 r. dotarła do Soł jego decyzja, iż Leszczyński ma wrócić do Polski, a po rozbiciu wojsk koronnych hetmana Sieniawskiego powinien wraz z wiernymi mu oddziałami polskimi i litewskimi oraz z towarzyszącymi im siłami szwedzkimi maszerować na Ukrainę. Jak pisał Jozafat Michał Karp: „co w wielkim jest sekrecie, a ja już o tym od trzech [osób] słyszałem"12. Informację tę potwierdził dwa tygodnie później powracający od Karola XII Stanisław Poniatowski (zaufany człowiek szwedzkiego monarchy), dodając, że królowi Stanisławowi „dano opcję, kiedy chce i którym traktem chce ruszyć do Polski"13. Zamiarem szwedzkiego władcy było uderzenie w kierunku Smoleńska i dalej na Moskwę. Spodziewał się, że Rosjanie zdecydują się na wydanie walnej bitwy, w której rozbije armię Piotra I i zmusi go do zawarcia pokoju na swoich warunkach. Chcąc szachować główne siły rosyjskie, zostawił liczny garnizon w Rydze, dodatkowo korpus szwedzki pod dowództwem gen. Adama Lewenhaupta miał wyruszyć z Kurlandii, by dołączyć do sił Karola XII, dostarczając niezbędne zaopatrzenie, a oddziały szwedzkie z Finlandii miały zaatakować zajętą przez Rosjan Ingrię (w tym i Petersburg). Zadaniem wojsk króla Stanisława wraz ze wspomagającym go korpusem szwedzkim miało być wtargnięcie na Ukrainę, połączenie się z Kozakami hetmana Iwana Mazepy, który obiecywał przejść na stronę Szwedów i uderzenie na główne siły rosyjskie, wraz z Karolem XII, od południa ${ }^{14}$.

Stanisław Leszczyński 15 czerwca 1708 r. wyruszył z Soł, 1 lipca był w Grodnie, stąd przez Prusy Brandenburskie udał się do Malborka ${ }^{15}$. Armia litewska hetmana Sapiehy tymczasem pozostała na terenach Wielkiego Księstwa Litewskiego, mając je ochraniać od wypadów lekkich oddziałów rosyjskich. Podróż króla Stanisława przez Prusy Brandenburskie wynikała z faktu, że Karol XII nie przydzielił mu żadnej eskorty szwedzkiej, tak więc obawiano się, by Leszczyński nie wpadł w ręce

12 Przy boku króla Stanisława, t. 1, s. 287 (J.M. Karp do K.S. Radziwiłła, Soły 25 V 1708).

13 Ibidem, s. 299 (J.M. Karp do K.S. Radziwiłła, Soły 8 VI 1708).

${ }^{14}$ J. Wimmer, op. cit., s. 326; A. Kamiński, Konfederacja sandomierska wobec Rosji w okresie poaltransztadzkim 1706-1709, Wrocław 1969, s. 137-138; B. Liljegren, op. cit. s. 154, 156-157, 159, 162-164; P. From, Klęska pod Połtawa. Kampania Karola XII w Rosji w latach 1707-1709, Zabrze 2010 (oryg. szw. 2007), s. 48-60.

${ }^{15}$ Przy boku króla Stanisława, t. 1, s. 311 (J.M. Karp do K.S. Radziwiłła, Soły 16 VI 1708). 
konfederatów sandomierskich, którzy kontrolowali znaczną część ziem polskich. Wycofanie się króla aż do Prus Królewskich wiązało się natomiast ze stacjonowaniem właśnie tam głównych sił szwedzkich pozostawionych w Rzeczypospolitej, które miały następnie iść wraz z oddziałami polskimi na południowy wschód, by rozbić wojska kwarciane hetmana Sieniawskiego i skierować się na Ukrainę. Dodatkowym argumentem przemawiającym za podróżą do Prus Królewskich była nadzieja na uzyskanie znaczącego wsparcia finansowego dla monarchy ze strony tamtejszego sejmiku generalnego oraz Gdańska. Leszczyński miał wówczas ciągłe kłopoty materialne, zwłaszcza że dochody z jego dóbr wielkopolskich znacząco spadły po ich spustoszeniu przez Rosjan i konfederatów sandomierskich. Pożyczka w wysokości przeszło 100 tys. talarów (624 tys. złp), którą zaciągnął 12 lipca 1707 r. u międzynarodowego bankiera Berenda Lehmanna, nie wystarczyła na długo ${ }^{16}$. Nie zawsze mógł liczyć na „dotacje” ze strony Karola XII, próbował więc, praktycznie bez skutku, pożyczać pieniądze od swych stronników, a nawet i dworzan.

Król Stanisław zjawił się w Malborku 7 lipca 1708 r. Tegoż dnia udał się z wizytą do stacjonującego w pobliżu na Żuławach gen. mjr. Krassowa, który miał dowodzić szwedzkim korpusem wspierającym wojska Leszczyńskiego ${ }^{17}$. Krassow, urodzony w 1660 r. na szwedzkim Pomorzu, już w wieku 17 lat rozpoczął służbę wojskową jako chorąży. Szybko, bo w 1678 r. awansował na porucznika, w 1688 (podczas kampanii w Holandii) na majora, a w 1698 r. został pułkownikiem dragonii. Uczestniczył w walkach na terenie Rzeczypospolitej podczas wojny północnej, m.in. w zdobyciu Lwowa w 1704 i bitwach pod Wschową i pod Kaliszem w 1706 r. W tymże roku otrzymał awans na gen. mjr. kawalerii. Dopiero jednak jesienią tego roku, po bitwie pod Kaliszem, Karol XII powierzył mu samodzielne zadanie. Stanął na czele niewielkiego korpusu (sześć pułków liczących około 6-7 tys. żołnierzy), który miał zająć pozycje wokół Poznania, by uniemożliwić oddziałom rosyjskim prowadzenie działań na terenie Wielkopolski. Krassow, zajęty głównie sprawami administracyjnymi i kwaterunkami, wysłał trzy pułki dragonii do Prus Królewskich. W tej sytuacji nie mógł przeszkodzić wtargnięciu Rosjan i wojsk koronnych w głąb Wielkopolski. Zrujnowały one tamtejsze dobra Leszczyńskiego, m.in. Leszno i Rydzynę. W ocenie szwedzkiego historyka Svena Grauersa Krassow był jednak „człowiekiem doświadczonym i zdolnym fachowcem

${ }^{16}$ K. Jarochowski, op. cit., s. 264; B. Strobach, Der Hofjude Berend Lehmann, BerlinBoston 2018, s. 310-311.

17 Przy boku króla Stanisława, t. 2, s. 13 (J.M. Karp do K.S. Radziwiłła, Malbork 7 VII 1708). 
o chłodnej i realistycznej ocenie sytuacji i możliwości"18, choć moim zdaniem nadawał się bardziej na generalnego kwatermistrza niż na dowódcę samodzielnego korpusu.

Podczas stosunkowo długiego pobytu w Malborku Leszczyński zajęty był próbami pozyskania hetmana wielkiego koronnego Adama Mikołaja Sieniawskiego, zabiegami o uchwalenie odpowiednich podatków przez obradujący tam właśnie sejmik generalny oraz o uzyskanie pieniędzy z Gdańska (bawił tam wtedy kilkakrotnie), a także amorami z piękną Marianną z Bielińskich Denhoffową ${ }^{19}$ (późniejszą metresą Augusta II). Pod względem finansowym pobyt króla w Prusach Królewskich był owocny. Sejmik generalny uchwalił zebranie 200 tys. złp, a Rada Gdańska, po długich targach (domagała się wycofania szwedzkich żołnierzy z Żuław Gdańskich), zdecydowała się przekazać Leszczyńskiemu 300 tys. złp. Znacznie gorzej było z realizacją planów przeciągnięcia na swoją stronę Sieniawskiego. Leszczyński obiecywał wprawdzie pozostawienie go na urzędzie hetmana wielkiego (wystawił nawet odpowiedni dokument), ale faktycznie było to uzależnione od uzyskania akceptacji Karola XII, który nie wyrażał na to zgody. Sieniawski o tym wiedział i ostatecznie 23 września 1708 r. przekazał wiadomość, iż gotów jest przejść na stronę króla Stanisława tylko wtedy, gdy opuści on szwedzkiego monarchę ${ }^{20}$. Aktywnie uczestniczyli w tej mediacji dyplomaci francuscy przebywający wówczas przy boku Leszczyńskiego, zwłaszcza Jean Louis d'Usson hrabia de Bonnac. Podejrzewali oni jednak, że król Stanisław niezbyt szczerze działa w tej sprawie, gdyż w istocie snuje marzenia o całkowitym rozbiciu swych przeciwników przez powracających z Rosji zwycięskich Szwedów, co pozwoliłoby mu znacząco wzmocnić swą pozycję ustrojową w Rzeczypospolitej w duchu absolutystycznym, a zwłaszcza przejąć rzeczywistą kontrolę nad wojskiem. Trudno powiedzieć, czy te opinie nie wynikały po prostu z mentalności tych dyplomatów, przekonanych o doskonałości systemu francuskiego absolutyzmu, do którego to wzorca

18 A. Lewenhaupt, Karl XII:s officerare. Biografiska anteckningar, Stockholm 1921, t. 2, s. 358; S. Grauers, Stosunek szwedzkich i polskich sił zbrojnych podczas wielkiej wojny pótnocnej, „Studia i Materiały do Historii Wojskowości” 20, 1976, s. 142-143, 145, 147 (cytat). Według Petera Froma (op. cit., s. 217) liczebność korpusu Krassowa idącego do Wielkopolski wynosiła 8 tys. ludzi.

19 J.A. Gierowski, Nieznany list miłosny Stanisława Leszczyńskiego do Marianny Denhoffowej, w: Ludzie, kontakty, kultura XVI-XVIII w. Prace ofiarowane Profesor Marii Boguckiej, red. J. Kowecki, J. Tazbir, Warszawa 1997, s. 167-169.

20 Zob. S. Achremczyk, Stanisław Leszczyński w Prusach Królewskich i w Prusach Ksiażęcych, „Komunikaty Mazursko-Warmińskie” 2006, 1, s. 73-76; J.M. Krzemiński, Od Sasa do Sasa. Królewskie popasy w Malborku, z kroniki malborskiej rezydencji jezuitów, „Rocznik Gdański” 45, 1985, 1, s. 186-189; J.A. Gierowski, W cieniu Ligi Północnej, s. 58-62. 
z natury rzeczy musi dążyć każdy władca, choć Bonnac powoływał się na rozmowy z samym Leszczyńskim i na informacje uzyskane od pewnych osób z dworu królewskiego ${ }^{21}$.

Podczas pobytu Stanisława Leszczyńskiego w Malborku miało nastąpić przygotowanie szwedzkiego korpusu do wymarszu. Tymczasem gen. Krassow ewidentnie się z tym nie spieszył. z listu Karpia wynika, że dopiero przed 4 września 1708 r. dotarły do Krassowa rozkazy Karola XII, „żeby regimenta były gotowe do wymarszu”. Wtedy też przybyły z Pomorza Szwedzkiego dwa regimenty dragonii, pułkowników Jürgena Friedricha Mellina i Gustafa Horna, oba w pełnym stanie liczbowym i dobrze wyekwipowane ${ }^{22}$. Mimo to nie widać było żadnych oznak pośpiechu. Możliwe, iż w związku z tym 9 września przybył do Malborka na inspekcję wojsk szwedzkich gen. Hans Isak Ridderhielm, gubernator Wismaru. Jak określał go Karp: „człowiek słyszę pobożności wielkiej i sumienia dobrego w swojej wierze, przy tym surowy wielce [--], po francusku mówi dobrze". Odbył on też długą konferencję z królem Stanisławem ${ }^{23}$. Mimo to jeszcze 25 września pisał Karp „o dalszym marszu cale głucho” i dodawał pogłoskę o możliwym zimowaniu w Prusach Królewskich ${ }^{24}$. Tegoż dnia zaczęto jednak mówić o możliwości wymarszu Szwedów, a nazajutrz pojawiła się wiadomość, iż król Stanisław ma wyruszyć do Tykocina ${ }^{25}$.

Zdaniem szwedzkiego historyka Grauersa zasadniczą przyczyną tak długiego postoju w Prusach Królewskich były rozbieżności między gen. Krassowem a królem Stanisławem. Szwedzki generał nie zamierzał podporządkowywać się polskiemu władcy, a Leszczyński (niemający zresztą żadnego wojennego doświadczenia) uważał, że to on „otrzymał od Karola XII dowództwo naczelne". Poza tym według tegoż badacza, król Stanisław mimo wszystko liczył na przeciągnięcie na swoją stronę armii koronnej hetmana Sieniawskiego, podczas gdy Krassow podobno uważał to za stratę czasu. Nie wiemy jednak, jakie były wówczas rzeczywiste plany Krassowa, gdyż jego raporty do Karola XII uległy zniszczeniu podczas bitwy pod Połtawą ${ }^{26}$, a z późniejszych działań generała wcale nie wynikało, by parł on do zbrojnej rozprawy z wojskami Sieniawskiego.

${ }^{21}$ J.A. Gierowski, Stanisław Leszczyński w latach 1707-1709 w opiniach dyplomatów francuskich, „Acta Universitatis Wratislaviensis. Historia” 36, 1981, s. 161-162.

${ }^{22}$ Przy boku króla Stanisława, t. 2, s. 41 (J.M. Karp do K.S. Radziwiłła, Malbork 6 IX 1708).

${ }^{23}$ Ibidem, s. 46 (J.M. Karp do K.S. Radziwiłła, Malbork 10 IX 1708).

${ }^{24}$ Ibidem, s. 63 (J.M. Karp do K.S. Radziwiłła, Malbork 25 IX 1708).

${ }^{25}$ Ibidem, s. 66 (J.M. Karp do K.S. Radziwiłła, Malbork 26 IX 1708).

${ }^{26}$ S. Grauers, op. cit., s. 146, 148 (cytat). 
O osobistej niechęci gen. Krassowa wobec króla Stanisława wspominał zresztą już dawno temu Kazimierz Jarochowski ${ }^{27}$.

Dopiero 10 października 1708 r. gen. Krassow pojawił się w Malborku, podejmując ostateczne przygotowania do wymarszu wojsk szwedzkich z Prus Królewskich. Podobno miał on niedawno odebrać nowe rozkazy Karola XII „do ruszenia się"28. Ostatecznie cztery kompanie z regimentu dragonii płk. Mellina przeszły przez Malbork 15 października:

szły naprzód konie powodne, potym jechał dobosz bijąc w kotły, za doboszem oboistowie, za nimi pułkownik na cudnym koniu gniadym siedzący, po którym solito ordine po dwu, ciągnął się regiment, lecz nie było tylko cztery chorągwie, każda po stu dwudziestu ludzi. Braku ni w koniach, ni w ludziach, ni w munderunku nie było. Ciągnęły się zatym tabory więcej dwóch godzin. Inne chorągwie tegoż regimentu bokiem przeszły ${ }^{29}$.

Następne oddziały szwedzkie przedefilowały przez Malbork dopiero 22 lub raczej 23 października 1708 r.:

Zacząwszy od jedynastej aż do wpół do wtórej przechodzili tędy: najprzód Francuzów [w służbie szwedzkiej - J.D.] chorągwi 4, było ludzi wszystkich 400; potym regiment dragoński JMP gen. Krassawa, mający chorągwi 8, pod każdą było ludzi sto dwadzieścia, albo koło stu trzydziestu; po nim regiment pomerański rajtarski, kornetów 8, pod każdym ludzi koło 70 liczyło się; na końcu przechodził regiment bremski [bremeński - J.D.] rajtarski, tyloż kornetów i tyloż ludzi mający. W tych dwóch ostatnich regimentach ludzie wszystko słuszni, bez żadnego braku ${ }^{30}$.

Z relacji Karpia wynikałoby, że liczebność korpusu gen. Krassowa, który miał osłaniać króla Stanisława, wynosiła około 4 tys. żołnierzy, wyłącznie kawalerii (trzy regimenty dragonii i dwa regimenty rajtarii). Trzeba tu jeszcze doliczyć część regimentu płk Klaësa Ekeblada, stacjonującego w Elblągu, oraz żołnierzy obsługujących artylerię i tabory. Z jednostek polskich bezpośrednio przy Leszczyńskim znajdował się tylko regiment gwardii pieszej płk. Michała Tarły liczący kilkuset ludzi (400?) oraz kilka chorągwi janczarskich i przyboczni drabanci (gwardziści) w liczbie 200 (przypuszczalnie Szwedzi). Łącznie siły te chyba nie przekraczały 6 tys. Co prawda szwedzki historyk Nils Herlitz podaje,

${ }^{27}$ K. Jarochowski, op. cit., s. 256. 1708).

${ }^{28}$ Przy boku króla Stanisława, t. 2, s. 78 (J.M. Karp do K.S. Radziwiłła, Malbork 12 X

${ }^{29}$ Ibidem, s. 83 (J.M. Karp do K.S. Radziwiłła, Malbork 16 X 1708).

30 Ibidem, s. 94 (J.M. Karp do K.S. Radziwiłła, Malbork 22 lub 23 X 1708). 
że gen. Krassow na początku operacji dysponował około 10 tys. żołnierzy, liczba ta wydaje się jednak ewidentnie zawyżona ${ }^{31}$.

Pewne wątpliwości budzi data wyjścia korpusu Krassowa z Prus Królewskich. Autor monumentalnej historii Karola XII, jego kaznodzieja nadworny, Joran (Georges) Nordberg, podawał, iż dwa regimenty wyruszyły 16 września 1708 r. (starego stylu, czyli 26 września), zamierzając przejść przez Wisłę po moście wzniesionym pod Grudziądzem. Na skutek informacji o szerzącej się w Polsce epidemii dżumy gen. Krassow wstrzymał marsz i oddziały wróciły na dotychczasowe kwatery na Żuławach. Ponownie wyruszono z początkiem października (starego stylu) i 6 tegoż miesiąca (czyli 16 X 1708) Krassow zatrzymał się w Tczewie, a 9 (czyli 19) października oddziały szwedzkie zaczęły przechodzić przez most pod Grudziądzem, kierując się na Brodnicę. Ponieważ most się zerwał i trzeba było go naprawiać, główna część sił szwedzkich, pułk Tarły oraz jakaś polska jazda przekroczyły Wisłę w ciągu następnych dwóch dni ${ }^{32}$. Trzeba jednak pamiętać, iż Nordberg przebywał wówczas w Rosji przy boku Karola XII i wydarzenia w Polsce opisywał na podstawie późniejszych relacji. Współczesny szwedzki historyk Peter From stwierdził niedawno, iż Krassow wyruszył z Malborka rzeczywiście 16 października $1708 \mathrm{r}^{33}$ Tego samego dnia mógł pojawić się w pobliskim Tczewie.

Sam król Stanisław pozostał jeszcze w Malborku (w związku z chorobą królowej Katarzyny) i dopiero 25 października 1708 wyjechał do Elbląga, skąd przez Warmię i Prusy Brandenburskie (odwiedził tam sanktuarium maryjne w Świętej Lipce) udał się do Tykocina. Dotarł do tego miasta 8 listopada i pozostał przez trzy tygodnie. Potem nadal kwaterował w kilku miejscowościach na Podlasiu w pobliżu Drohiczyna, Siedlec i Łukowa. 8 stycznia 1709 r. przeniósł się w okolice Parczewa w Lubelskiem, od końca stycznia przebywał w okolicach Chełma (przez pewien czas mieszkał w samym Chełmie), po czym z początkiem marca $1709 \mathrm{r}$. przesunął się w pobliże Tomaszowa Lubelskiego, a 25 marca stanął w Lubaczowie. W dniu 1 kwietnia 1709 r. zajął kwaterę w dawnym pałacyku Sobieskich w Wysocku pod Jarosławiem ${ }^{34}$. Przez cały czas towarzyszyła mu szwedzka kawaleria gen. Krassowa, która kwaterowała w pobliskich

31 N. Herlitz, Den polska frågan 1708-1709, „Karolinska Forbundets Årsbok” 1914, s. 160; zob. też S. Grauers, op. cit., s. 147. Możliwe, że Herlitz doliczył do korpusu Krassowa także garnizony poznański i elbląski oraz inne drobniejsze oddziały szwedzkie rozlokowane w Polsce i Litwie.

${ }^{32}$ G.A. Nordberg, Histoire de Charles XII, roi de Suede, t. 2, La Haye 1748, s. 257-258.

33 P. From, op. cit., s. 221.

${ }^{34}$ Itinerarium króla Stanisława przedstawiłem na podstawie listów J.M. Karpia do K.S. Radziwiłła (5 XI 1708 - 7 IV 1709), zob. Przy boku króla Stanisława, t. 2, s. 95-188. 
miejscowościach, a także kilka polskich chorągwi janczarskich, regiment gwardii pieszej płk. Tarły oraz 200 przybocznych drabantów ${ }^{35}$.

Według koncepcji dowództwa szwedzkiego wojsko litewskie dowodzone przez hetmana Jana Kazimierza Sapiehę, liczące około 12 tys. żołnierzy, miało zabezpieczać lewą flankę korpusu gen. Krassowa i kierować się na Brześć Litewski, podczas gdy oddziały koronne wierne królowi Stanisławowi w sile około 9-10 tys. ludzi, znajdujące się pod komendą wojewody kijowskiego Józefa Potockiego (hetmana wielkiego koronnego z nominacji króla Stanisława), powinny posuwać się w kierunku województwa sandomierskiego, a następnie przejść przez Wisłę do województwa lubelskiego i wkroczyć stamtąd na Wołyń ${ }^{36}$. Niespodziewanie Potocki zaatakował 21 listopada 1708 r. pod Koniecpolem dywizję regimentarza Jakuba Zygmunta Rybińskiego i został całkowicie rozbity. Resztki jego sił wycofały się na Mazowsze, by potem skierować się w ślad za Leszczyńskim na Podlasie. Zwycięski Rybiński przeszedł przez Wielkopolskę i wkroczył do Prus Królewskich, przez dłuższy czas blokując szwedzkie garnizony w Poznaniu i Elblągu ${ }^{37}$. W tej sytuacji poszczególne oddziały wojsk koronnych podporządkowane konfederacji sandomierskiej i hetmanowi Sieniawskiemu skutecznie niepokoiły korpus gen. Krassowa, spowalniając jego marsz. Przykładowo wieczorem 13 stycznia 1709 r. pojawiła się pogłoska o zbliżaniu się kilkutysięcznego podjazdu wojsk kwarcianych do kwatery króla Stanisława w Siemieniu w województwie lubelskim.

Wielka tedy stąd trwoga stała się. Zaraz posłał Król JM pana [Józefa] Poniatowskiego do JP [Ernsta Detlofa] Krassawa, który sto kilkadziesiąt ludzi swoich przysłał pro praesidio Królowi JM. Sprowadzono 400 piechoty tarłowskiej ${ }^{38}$, janczarów i drabantów. Ci wszyscy ludzie całą noc vigilabant we dworze i koło dworu w którym stał Król JM w Siemieniu. [- - ] Aż dopiero wczoraj [14 stycznia], około dziesiątej godziny evanuit ten rumor i pokazało się, że tylko kilkadziesiąt ludzi kwarcianych było pod Łęczną i rejterowali się nazad za Lublin ${ }^{39}$.

Tymczasem hetman wielki litewski Sapieha, na wiadomość o klęsce armii szwedzkiej gen. Lewenhaupta, spieszącej z Inflant z pomocą Karolowi XII, w bitwie pod Leśną w dniach 9-10 października 1708 r., zajął się

\footnotetext{
35 J. Wimmer, op. cit., s. 323.

36 Ibidem, s. 331.

37 Ł. Pabich, Bitwa pod Koniecpolem 21 listopada 1708, Zabrze-Tarnowskie Góry 2014.

${ }^{38} \mathrm{Z}$ regimentu piechoty płk. Michała Tarły.

${ }^{39}$ Przy boku króla Stanisława, t. 2, s. 132-133 (J.M. Karp do K.S. Radziwiłła, Tulniki
} 15 I 1709). 
wzmacnianiem swych sił zbrojnych i zabezpieczaniem granic Wielkiego Księstwa Litewskiego przed wypadami wojsk rosyjskich. Nie przejawiał też ochoty, by łączyć się z korpusem gen. Krassowa. Opieszałość hetmana w pewnej mierze mogła wynikać z jego poufnych kontaktów z hetmanową Elżbietą Sieniawską, która próbowała nakłonić go do przejścia na stronę konfederacji sandomierskiej ${ }^{40}$. Krassow 17 stycznia 1709 r. zdecydowanie więc zażądał, by Sapieha „ruszył wojsko litewskie”. W kilka dni później król Stanisław z kilkoma osobami sam pojechał do hetmana. Spotkał się z nim w Tewelach pod Kobryniem, nie przyniosło to jednak większego efektu ${ }^{41} .21$ lutego 1709 r. Leszczyński ponownie więc ponaglat hetmana, ,ażeby jak najprędzej pośpieszał z wojskiem”42. Dopiero w drugiej połowie marca 1709 r. Sapieha skoncentrował swe siły, liczące około 5 tys. kawalerii, i ruszył na Wołyń. Decydowały o tym z jednej strony względy zaopatrzeniowe, z drugiej chęć rozbicia stojącej tam litewskiej dywizji Hrehorego Ogińskiego, współdziałającej z wojskami koronnymi hetmana Adama Mikołaja Sieniawskiego. Ogiński, hetman polny litewski z nominacji Augusta II, był traktowany przez Sapiehę jako konkurent do buławy wielkiej ${ }^{43}$.

Peter From postawił tezę, iż powolny marsz korpusu gen. Krassowa na południowy wschód wynikał m.in. z nieporozumień między szwedzkim dowódcą a królem Stanisławem. Według tego autora Leszczyński wyraźnie pragnął uniknąć generalnego zbrojnego starcia z przeciwnikami i cały czas, mimo wcześniejszych niepowodzeń, podejmował próby przeciągnięcia na swoją stronę hetmana Sieniawskiego (m.in. za pośrednictwem dyplomatów francuskich i biskupa chełmińskiego Teodora Potockiego). Hetman zresztą ewidentnie zwodził Leszczyńskiego, czekając na ostateczny wynik kampanii rosyjskiej Karola XII ${ }^{44}$. Według Froma, Krassow, zgodnie z wcześniejszymi rozkazami szwedzkiego monarchy, chciał naprzód rozbić siły konfederacji sandomierskiej i dopiero potem podjąć marsz na Ukrainę $e^{45}$. Analizując informacje zawarte w listach (a właściwie to w diariuszu) Karpia nie widzimy jednak żadnych przejawów determinacji Krassowa w atakowaniu wojsk kwarcianych hetmana

${ }^{40}$ T. Ciesielski, Kariera wojskowa Jana Kazimierza Sapiehy, w: Wielkie rody dawnej Rzeczypospolitej XVI-XIX wieku, t. 1: Sapiehowie, red. T. Ciesielski, M. Sawicki, Opole 2018, s. 344-345.

${ }^{41}$ Przy boku króla Stanisława, t. 2, s. 140 i 142 (J.M. Karp do K.S. Radziwiłła, Siemień 24 I 1709; Tulniki 28 I 1709).

${ }^{42}$ Ibidem, s. 160-161 (J.M. Karp do K.S. Radziwiłła, Chełm 21 II 1709).

43 T. Ciesielski, Kariera wojskowa, s. 346-347.

44 A. Kamiński, op. cit., s. 142.

45 P. From, op. cit., s. 222. 
Sieniawskiego. Ograniczał się on raczej do obrony przed wypadami oddziałów koronnych i wysyłaniem podjazdów, które niewiele mogły zdziałać. Dlatego też w jednym z listów Karp złośliwie zauważył, iż dwa regimenty szwedzkiej kawalerii właśnie powróciły z podjazdu, jak zwykle „nie dotarłszy tam gdzie należało" 46 .

W rzeczywistości główną przyczyną powściągliwości gen. Krassowa była chyba świadomość, iż dysponuje on zbyt szczupłymi siłami, by podejmować bardziej zdecydowane akcje ofensywne, zwłaszcza że przez dłuższy czas nie mógł liczyć na skuteczne wsparcie ze strony oddziałów hetmana Jana Kazimierza Sapiehy i wojewody kijowskiego Józefa Potockiego. Do podobnego wniosku doszedł zresztą Karol XII, mimo iż łączność pomiędzy jego armią a Szwecją i ziemiami Rzeczypospolitej była praktycznie przerwana przez Rosjan. W grudniu $1708 \mathrm{r}$. wysłał on rozkazy do dowódców szwedzkich garnizonów w Elblągu i Poznaniu oraz wojsk pozostawionych na Pomorzu Szczecińskim, by gubernator Wismaru gen. Hans Isak Ridderhielm, na czele ośmiu regimentów piechoty (9,6 tys. ludzi), wzmocnionych dwoma batalionami z Elbląga i pułkiem dragonii liczącym 900 żołnierzy wyruszył z Pomorza i wsparł działania kawalerii gen. Krassowa. Informacje te dotarły do kwatery szwedzkiej z dużym opóźnieniem, sporo czasu zabrała koncentracja tych sił, tak że Ridderhielm dopiero w maju 1709 r. wkroczył do Wielkopolski ${ }^{47}$. Do króla Stanisława wiadomość, iż Karol polecił regimentom szwedzkiej piechoty iść na pomoc gen. Krassowowi, dotarła bardzo późno, bo 27 kwietnia 1709 r. $^{48}$

Dodatkową przyczyną braku ofensywnych akcji gen. Krassowa i oddziałów stanisławowskich były pojawiające się od końca stycznia 1709 r. pogłoski o pojawieniu się na Wołyniu znacznych sił rosyjskich, które miały wzmocnić znajdujące się tam polsko-litewskie wojska hetmanów Adama Mikołaja Sieniawskiego i Hrehorego Ogińskiego. Informacje te były jednak sprzeczne, bo naprzód była mowa, iż korpus rosyjski liczy 15 tys. żołnierzy i aż 21 tys. Kozaków, potem (16 marca), że 3 tys. żołnierzy rosyjskich dołączyło do dywizji Ogińskiego, a dodatkowo nadciąga sześć regimentów piechoty i tyleż regimentów kawalerii, wreszcie kilka dni później przyszła wiadomość, iż na Wołyniu jest tylko 800 Rosjan ${ }^{49}$.

${ }^{46}$ Przy boku króla Stanisława, t. 2, s. 231 (J.M. Karp do K.S. Radziwiłła, Jarosław 31 V 1709).

47 G.A. Nordberg, op. cit., s. 357.

${ }^{48}$ Przy boku króla Stanisława, t. 2, s. 207-208 (J.M. Karp do K.S. Radziwiłła, Wysocko [3 V] 1709).

${ }^{49}$ Ibidem, s. 144, 161, 180 i 184 (J.M. Karp do K.S. Radziwiłła, Tulniki 28 I 1709, Chełm 21 II 1709, Machnów 17 i 22 III 1709). 
Sytuacja militarna uległa zmianie na korzyść Szwedów i wojsk króla Stanisława na przełomie marca i kwietnia 1709 r. Dywizja hetmana litewskiego Jana Kazimierza Sapiehy, nie napotykając oporu, wkroczyła na Wołyń. Już wcześniej, bo 7 marca hetman koronny Sieniawski wycofał ze Lwowa swój garnizon. Wykorzystał to król Stanisław i 13 marca rano wyprawił do tego miasta swój przyboczny pułk piechoty pod dowództwem płk. Michała Tarły. Tego samego dnia wojewoda kijowski Józef Potocki na czele swych na nowo zebranych oddziałów zajął kwatery w okolicach Żółkwi, po czym z większością swej dywizji poszedł za Lwów w ślad za wycofującymi się na południe wojskami konfederacji sandomierskiej, rozlokowawszy swe siły w Kałuszu, Stryju i Drohobyczu ${ }^{50} .22$ marca do obozu króla Stanisława dotarła wiadomość, że pułk Tarły dotarł do Lwowa (zapewne około 17-18 marca), a na miasto kontrybucje nałożyli dodatkowo wojewoda Potocki i Szwedzi. Mieszczanie mieli być tak obciążeni, że „z przedmieścia ludzie nawet pouciekali”51. Do przebywającej w Skolem, małym mieście na południe od Stryja, hetmanowej wielkiej koronnej Elżbiety Sieniawskiej doszły informacje, iż Tarło zażądał od Lwowa 10 tys. talarów (60 tys. złp) dla króla Stanisława w formie pożyczki, ponadto kwater, żywności i wypłaty żołdu dla swych żołnierzy. Domagał się też jakichś pieniędzy (,,barankowego”) od lwowskich klasztorów, konfiskował szlacheckie zboża trzymane w tamtejszych spichrzach, zabrał z miejskiego arsenału resztę uzbrojenia, którego nie skonfiskowali Szwedzi w 1704 r., a mieszczanie mieli dostarczyć 500 par butów i 500 janczarek (strzelb) dla „semenów” (to jest jazdy wołoskiej) króla Stanisława. Ponadto ludzie Tarły podobno zabierali towary kupcom lwowskim ${ }^{52}$. W dotychczasowej literaturze, w ślad za informacjami z gazet pisanych, wspominano o kontrybucji w wysokości 20 tys. talarów (czyli 120 tys. złp) ${ }^{53}$ lub 10 tys. talarów (60 tys. złp) dla Leszczyńskiego, 15 tys. złp dla wojska i 27 tys. złp dla płk. Tarły jako nowego komendanta miasta, w sumie 102 tys. złp ${ }^{54}$.

${ }^{50}$ Nowiny z r. 1706, 1707, 1708, 1709, wyd. S. Barącz, w: idem, Pamiętnik dziejów polskich. $Z$ aktów urzędowych lwowskich i z rękopisów, Lwów 1855, s. 158.

${ }^{51}$ Przy boku króla Stanisława, t. 2, s. 185 (J.M. Karp do K.S. Radziwiłła, Machnów 22 III 1709). Nie mamy informacji o wkroczeniu wówczas do Lwowa oddziałów Potockiego i Szwedów, co nie oznacza, że tak Potocki, jak i poszczególni dowódcy szwedzcy nie mogli wysłać do miasta komisarzy z zadaniem poboru kontrybucji.

${ }^{52}$ Korespondencja Elżbiety z Lubomirskich Sieniawskiej, kasztelanowej krakowskiej, t. 1: Z serca kochająca żona i uniżona sługa. Listy Elżbiety z Lubomirskich Sieniawskiej do męża Adama Mikołaja Sieniawskiego z lat 1688-1726, wyd. B. Popiołek, U. Kicińska, A. Słaby, Warszawa-Bellerive-sur-Allier 2016, s. 232 (list ze Skolego z 8 IV 1709).

${ }^{53}$ A. Perłakowski, op. cit., s. 268; Nowiny z r. 1706, 1707, 1708, 1709, s. 158 (w tym 10 tys. talarów jako pożyczka) - gazeta pisana, Ze Lwowa 4 IV 1709.

${ }^{54}$ J.A. Gierowski, W cieniu Ligi Pótnocnej, s. 74. 
Stanisław Leszczyński po zajęciu Lwowa przez żołnierzy płk. Tarły zachęcał 26 marca 1709 r. gen. Krassowa do przesunięcia głównych sił szwedzkich pod Jarosław, tak by mogły szybko przejść aż do stolicy województwa ruskiego. Szwedzki generał wymawiał się różnymi przeszkodami. Co więcej, okazał wyraźne niezadowolenie z zajęcia przez oddziały Józefa Potockiego kwater wokół Żółkwi, gdyż z tych terenów Krassow zamierzał ściągać kontrybucje i żywność dla swoich żołnierzy ${ }^{55}$. Istotną przyczyną niechęci szwedzkiego dowódcy do szybkiej ofensywy było chyba pozostawienie przez hetmana Sieniawskiego na tyłach jego korpusu, w Małopolsce, znacznego zgrupowania wojsk kwarcianych ${ }^{56}$.

Tymczasem 28 marca 1709 r. dotarła do króla Stanisława wiadomość (jak się potem okazało przedwczesna) o całkowitym rozbiciu przez hetmana litewskiego Jana Kazimierza Sapiehę obozujących pod Lachowicami na wschód od Krzemieńca sił Hrehorego Ogińskiego. Ponadto 5 kwietnia napłynęły informacje od szpiegów z Połonnego na Ukrainie upewniające, iż żadne wojska rosyjskie w najbliższym czasie nie wkroczą do Rzeczypospolitej ${ }^{57}$. Dlatego też król Stanisław zdecydował się wyruszyć do Lwowa. Wczesnym przedpołudniem 10 kwietnia monarcha, eskortowany przez oddział przybocznych drabantów, wyjechał z Wysocka i o godzinie drugiej po południu zatrzymał się w Jaworowie, starostwie należącym wciąż do królowej wdowy Marii Kazimiery Sobieskiej. Z senatorów towarzyszyli mu biskup chełmiński (nominat krakowski) Teodor Potocki i biskup kijowski Jan Paweł Gomoliński. Po przyjeździe do Jaworowa król przechadzał się po tamtejszym dworze i ogrodzie, zjadł obiad u komisarza starostwa, niejakiego Zasieckiego, i nocował w apartamentach królowej ${ }^{58}$.

Następny dzień spędził Stanisław Leszczyński w Jaworowie, czekając na regimenty szwedzkie, które dopiero dotarły do pobliskiej wsi Szczerzec. Król uczestniczył we mszy w jaworowskim kościele, a po obiedzie bawił się strzelaniem z łuku z konia i pieszo. Tegoż dnia do Jaworowa dotarł zaufany człowiek Leszczyńskiego, marszałek nadworny koronny Stanisław Tarło, a po południu przyjechał dyplomata francuski Jean Louis Bonnac, który od dłuższego czasu pośredniczył między

55 Przy boku króla Stanisława, t. 2, s. 174, 177, 179, 181 i 190 (J.M. Karp do K.S. Radziwiłła, Machnów 14, 17 i 18 III; Lubaczów 27 III; Wysocko 7 IV 1709).

${ }^{56}$ J.A. Gierowski, W cieniu Ligi Pótnocnej, s. 73.

${ }^{57}$ Przy boku króla Stanisława, t. 2, s. 189, 194-195 (J.M. Karp do K.S. Radziwiłła, Wysocko 7 IV 1709).

${ }^{58}$ Cały opis podróży i pobytu króla Stanisława we Lwowie oparty jest na szczegółowej relacji (diariuszu) J.M. Karpia sporządzonej 21 IV 1709 we Lwowie dla K.S. Radziwiłła (Przy boku króla Stanisława, t. 2, s. 196-205). 
hetmanem Sieniawskim, a królem Stanisławem. Podkanclerzy litewski Stanisław Antoni Szczuka, wysłany do hetmana litewskiego Jana Kazimierza Sapiehy przysłał wiadomość, iż ten „ruszył się z całym wojskiem na Moskwę i [Hrehorego] Ogińskiego" i jutro lub pojutrze na niego uderzy. Bardzo ucieszyło to króla Stanisława ${ }^{59}$.

\section{We Lwowie}

W piątek 12 kwietnia bezpośrednio po mszy monarcha wyjechał z Jaworowa, zatrzymał się na późny obiad w Janowie, wsi na zachód od Lwowa i tuż przed wieczorem ruszył do tego miasta. Zjawił się tam około godziny dziewiątej wieczorem, brama była już jednak zamknięta i musiano z pół godziny czekać na jej otwarcie. Tłumaczono się, że oficer z kluczami gdzieś poszedł, ale jak się później dowiedział Jozafat Michał Karp, warta przy bramie była nieliczna i nieprzygotowana, musiano więc ją odpowiednio wzmocnić, by mogła oddać honory należne monarsze. Po wjeździe do Lwowa król udał się do przebywającego tam w swej kamienicy w Rynku chorążego koronnego Aleksandra Jana Jabłonowskiego, u którego spędził dwie godziny. Potem wrócił do swojej kwatery w kamienicy księżny Anny Wiśniowieckiej Dolskiej po przeciwnej stronie Rynku, obok kamienicy arcybiskupów lwowskich. Tegoż dnia przyszła do Lwowa wiadomość, iż obaj hetmani koronni, Adam Mikołaj Sieniawski i Stanisław Rzewuski, wycofali się aż do Tarnopola ${ }^{60}$.

Następnego dnia, 13 kwietnia, z samego rana przybyli lwowscy kupcy ormiańscy, aby ofiarować królowi Stanisławowi różnorodne bogate tkaniny. Monarcha je obejrzał, potem się ubrał i poszedł do sąsiedniej kamienicy arcybiskupiej (Rynek nr 9), w której rezydował w tym czasie biskup chełmiński Teodor Potocki. Przywitał tam króla biskup sufragan lwowski Jan Skarbek oraz delegacje miejscowych domów zakonnych. Mszy wysłuchał Leszczyński w swojej kwaterze w kaplicy. Później przeszedł piechotą na obiad do Aleksandra Jana Jabłonowskiego. Po południu przyjechał z Żółkwi królewicz Konstanty Sobieski, z którym król przez godzinę rozmawiał. Następnie monarcha przyjął wojewodę płockiego Jana Krasińskiego i koniuszego koronnego Jerzego Dzieduszyckiego. Potem pojechał do królewicza Konstantego, a po drodze odwiedził podkomorzynę koronną Urszulę z Bokumów Lubomirską, księżnę cieszyńską. Wieczorem naprzód konferował z Jeanem Louisem Bonnakiem i Stanisławem

59 Ibidem, s. 197.

${ }^{60}$ Ibidem, s. 198. 
Tarłą, a później w swoim pokoju grał w większym towarzystwie w karty. Kolację spożył u biskupa Teodora Potockiego. Uczestniczyli w niej m.in. królewicz Konstanty Sobieski, Aleksander Jan Jabłonowski z żoną Teofilą, Anna z Bokumów Wapowska (siostra Urszuli Lubomirskiej) i jej mąż stolnikowicz koronny Karol, Stanisław Tarło oraz Jerzy Dzieduszycki. Spotkanie uprzyjemniali muzyką królewscy „oboistowie”. Tegoż dnia ogłoszono we Lwowie wiadomość o śmierci arcybiskupa lwowskiego Konstantego Józefa Zielińskiego, który koronował Stanisława Leszczyńskiego. Został potem schwytany przez Rosjan i wywieziony do Moskwy, gdzie zmarł 17 lutego 1709 r. ${ }^{61}$

W niedzielę 14 kwietnia król Stanisław udał się rano pieszo do katedry na mszę. Po mszy przywitała go lwowska kapituła, po czym któryś z miejscowych jezuitów wygłosił kazanie, niezbyt wysoko ocenione przez Karpia. Z katedry monarcha w asyście królewicza Konstantego Sobieskiego, Stanisława Tarły, Aleksandra Jana Jabłonowskiego i innych dostojników wybrał się na obiad do krajczego koronnego Stefana Potockiego. Potem pojechał do klasztoru Benedyktynek, odwiedzając swoją krewną, ksienię Helenę Kazanowską. Cały wieczór spędził u chorążego koronnego Jabłonowskiego ${ }^{62}$.

Następnego dnia przed południem król Stanisław pozował do portretu, który malował były nadworny malarz Jana III, Jerzy Eleuter Siemiginowski. Ten znany artysta najpóźniej od września 1707 r. mieszkał we Lwowie, o jego ówczesnej twórczości praktycznie nic jednak nie wiadomo $^{63}$. Potem monarcha uczestniczył we mszy odprawionej w jego pokoju i poszedł na obiad do płk. Michała Tarły. Obecni na nim byli m.in. biskup Teodor Potocki, Stanisław Tarło, Aleksander Jan Jabłonowski, Jerzy Dzieduszycki, Jean Louis Bonnac, starosta malborski Franciszek Bieliński, Karol Wapowski, starosta gnieźnieński Adam Śmigielski (jeden z najlepszych dowódców wojsk stanisławowskich) i płk Józef Poniatowski, starszy brat Stanisława, który przebywał na Ukrainie, towarzysząc Karolowi XII. Jedzenie według Karpia było bardzo dobre, stół trzy razy zastawiano, podano też i desery, a po obiedzie wszyscy wypili sporo wina. Król wrócił jeszcze do swej kwatery, gdzie Siemiginowski kończył

${ }^{61}$ Ibidem, s. 198-199; zob. też S. Szydelski, Konstanty Zieliński arcybiskup lwowski, Kraków 1910, s. 172-173.

${ }^{62}$ Przy boku króla Stanisława, t. 2, s. 199-200 (J.M. Karp do K.S. Radziwiłła, Lwów 21 IV 1709).

${ }^{63}$ Ostatnia informacja o Jerzym Eleuterze Siemiginowskim, jaką podaje jego biograf Mariusz Karpowicz pochodzi z 17 września 1707 r., wiadomo też, że 13 marca 1711 w księgach miejskich Lwowa jest wymieniony jako zmarły, zob. M. Karpowicz, Jerzy Eleuter Siemiginowski, malarz polskiego baroku, Wrocław-Warszawa 1974, s. 37. 
malować jego portret ${ }^{64}$. Potem całe towarzystwo spotkało się na kolacji u biskupa Potockiego. Pojawiły się tam też dwie damy, chorążyna koronna Teofila Jabłonowska i stolnikowiczowa koronna Anna Wapowska, którą zresztą nieco później posądzano o romans z królem ${ }^{65}$.

Tegoż dnia (15 kwietnia) dotarła do Lwowa wiadomość (tym razem prawdziwa) o zwycięstwie pod Lachowcami wojsk hetmana Jana Kazimierza Sapiehy nad dywizją Hrehorego Ogińskiego i wspierającymi go żołnierzami rosyjskimi. W rzeczywistości oddziały Ogińskiego 11 kwietnia 1709 r. doznały wyraźnej porażki i pospiesznie wycofały się, nie zostały jednak rozbite ${ }^{66}$.

We wtorek 16 kwietnia rano król Stanisław naradzał się z królewiczem Konstantym Sobieskim, biskupem Teodorem Potockim i Adamem Śmigielskim. Potem udał się na mszę do pobliskiego kościoła Jezuitów, gdzie przywitał go rektor lwowskiego kolegium jezuickiego Jan Janiszewski. Na obiedzie król był wraz z grupą dostojników u biskupa Potockiego. Następnie rozmawiał w swoim gabinecie z kilkoma osobami, m.in. z Aleksandrem Janem Jabłonowskim, po czym złożył wizytę podkoniuszynie koronnej Ludwice Ponińskiej. Tam jej córka Teresa zabawiała go grą na różnych instrumentach. Kolację dla monarchy wydawał Karol Wapowski. Przed je podaniem zabawiano się kartami, król grał m.in. z królewiczem Konstantym, Jeanem Louisem Bonnac i Anną Wapowską. Bank trzymał królewski generał adiutant, Szwed Henrik Klingstedt. Najwięcej stracił płk Michał Tarło, bo dwieście kilkadziesiąt dukatów (przeszło 4,5 tys. złp). W tym dniu chorąży koronny Jabłonowski podarował Stanisławowi portret kozackiego hetmana Iwana Mazepy, który przeszedł na stronę szwedzką. Król bardzo był zadowolony i zaraz kazał powiesić ten obraz w swoim pokoju. Przyszła też wiadomość, jakoby hetman litewski Jan Kazimierz Sapieha otoczył resztę dywizji Ogińskiego gdzieś za Lachowcami ${ }^{67}$.

Rankiem następnego dnia, 17 kwietnia, wyjechał ze Lwowa królewicz Konstanty Sobieski. Udał się on do Skolego, gdzie przebywała wówczas

${ }^{64} \mathrm{~W}$ dotychczasowej literaturze portret ten nie jest odnotowany, zob. Stanisław Leszczyński. Król Polski księciem Lotaryngii. Wystawa w Zamku Królewskim w Warszawie 25 kwietnia - 10 lipca 2005 roku, red. katalogu Z. Jurkowlaniec, Warszawa 2005; H. Widacka, Z króla ksiązę. Stanisław Leszczyński w grafice XVIII wieku ze zbiorów polskich i francuskich, Warszawa 2006.

${ }^{65}$ Przy boku króla Stanisława, t. 2, s. 225 (J.M. Karp do K.S. Radziwiłła, Wysocko 23 V 1709).

${ }^{66}$ T. Ciesielski, Ostatnie tryumfy bitewne oręża Wielkiego Księstwa Litewskiego - bitwy pod Lachowcami i Nakwasza, w: Vaennyâ tryumfy epohi Vâlikaga Knâstva Lìtoŭskaga. Zbornik navukovyh artykulaŭ, red. M.N. Gal'pârovič, Mir 2017, s. 256-259.

67 Przy boku króla Stanisława, t. 2, s. 201-202 (J.M. Karp do K.S. Radziwiłła, Lwów 21 IV 1709). 
Elżbieta Sieniawska. Wyjazd ten był uzgodniony z królem Stanisławem i świadczy o kontynuowaniu zabiegów zmierzających do przeciągnięcia hetmana Sieniawskiego na stronę stanisławowską. Tym razem królewicz Sobieski miał jednak ostro zażądać ostatecznej deklaracji ze strony hetmana, grożąc w przeciwnym razie wyciągnięciem konsekwencji ${ }^{68}$. Na ten twardszy ton ze strony Leszczyńskiego miały chyba wpływ sukcesy jego wojsk i stopniowe wycofywanie się oddziałów hetmańskich na południowy wschód. Sam monarcha wysłuchał mszy w swoim pokoju, potem udał się na obiad do Aleksandra Jana Jabłonowskiego, a po powrocie do swej kwatery przespał się przez kilka godzin. Późnym popołudniem złożyły mu dłuższą wizytę Teofila Jabłonowska i Anna Wapowska. Kolację zjadł król w sąsiedniej kamienicy u biskupa Teodora Potockiego ${ }^{69}$.

W czwartek 18 kwietnia Stanisław Leszczyński od samego rana zajęty był załatwianiem korespondencji. Wysłał listy m.in. do hetmana litewskiego Jana Kazimierza Sapiehy oraz do gen. Ernsta Detlofa Krassowa, który nie zdecydował się podejść pod Lwów, a także do swych stronników w Wielkopolsce. Odbył też jakąś naradę z koniuszym koronnym Jerzym Dzieduszyckim po czym, tak jak i poprzednio, wysłuchał w swoim pokoju mszy. Następnie rozmawiał z biskupem Teodorem Potockim i zjadł u niego obiad. Potem konno w towarzystwie kilkunastu osób pojechał do klasztoru i kolegium Teatynów pod Wysokim Zamkiem, wracając wstąpił do mocno zrujnowanego pałacu nieżyjącego już hetmana wielkiego koronnego i kasztelana krakowskiego Stanisława Jana Jabłonowskiego. Stamtąd udał się do klasztoru Benedyktynek, gdzie ponownie spotkał się z ksienią Heleną Kazanowską. Wieczór spędził u Aleksandra Jana Lubomirskiego, tam grał w tryktraka (grę planszową) z Anną Wapowską. Kolacji nie jadł i stosunkowo wcześnie poszedł spać ${ }^{70}$.

W piątek 19 kwietnia z samego rana nadeszła do Lwowa wiadomość, iż hetman Jan Kazimierz Sapieha, po zwycięskiej bitwie z oddziałami Hrehorego Ogińskiego, niespodziewanie cofnął się z Lachowiec do Beresteczka, gdzie dla większego bezpieczeństwa kazał sypać okopy wokół obozu. Oznaczało to, iż wojska litewskie na razie nie zamierzają kontynuować ofensywy przeciw siłom konfederacji sandomierskiej, choć z innych doniesień wynikało, że hetmani koronni Adam Mikołaj Sieniawski i Stanisław Rzewuski, obawiając się ataku wojsk Józefa Potockiego,

${ }^{68}$ Królewicz Konstanty zabawił dłuższy czas u Elżbiety Sieniawskiej w Skolem, z jej listu z 10 maja 1709 r. wynikałoby, że odradzał on królowi Stanisławowi stosowanie gróźb wobec hetmana, zob. Korespondencja Elżbiety z Lubomirskich Sieniawskiej, s. 236.

${ }^{69}$ Przy boku króla Stanisława, t. 2, s. 202-203 (J.M. Karp do K.S. Radziwiłła, Lwów 21 IV 1709).

70 Ibidem, s. 202-203. 
wycofują się w stronę Kamieńca Podolskiego. Tegoż dnia król Stanisław uczestniczył we mszy przed cudownym obrazem Matki Boskiej Łaskawej, umieszczonym na zewnętrznej ścianie prezbiterium katedry łacińskiej. Potem w kwaterze biskupa Teodora Potockiego rozmawiał z dyplomatą francuskim Jeanem Louisem Bonnakiem i samym biskupem. U niego też był na obiedzie. Wieczorem pojechał wraz z Aleksandrem Janem Jabłonowskim na przedmieście do dworku lwowskiego burmistrza Tomasza Gordona. Na skutek ulewy obaj szybko wrócili do miasta i Leszczyński aż do nocy „bawił się” u Jabłonowskiego ${ }^{71}$.

Dopiero w sobotę 20 kwietnia, sześć dni po przybyciu króla Stanisława do Lwowa, odbyła się rano audiencja władz miejskich u monarchy. Przedstawiciel rady prosił o złagodzenie ciężarów nałożonych na Lwów. Zapewne przypomniał przy tej okazji wydarzenia z 1704 r., kiedy to dzięki wstawiennictwu Leszczyńskiego Szwedzi obniżyli nieco swoje żądania finansowe względem miasta. $\mathrm{W}$ imieniu króla odpowiedział marszałek nadworny koronny Stanisław Tarło, obiecując miastu łaskę królewską. Karp nie informuje, czy przy tej okazji nie było też mowy o sprawie pożyczki dla monarchy w wysokości 60 tys. złp, na udzielenie której nalegał uprzednio płk Michał Tarło. Po audiencji król Stanisław uczestniczył we mszy odprawionej w jego pokoju. Następnie w kolasce Jeana Louisa Bonnaka pojechał do dworku burmistrza Tomasza Gordona. Tam starosta malborski Franciszek Bieliński gościł monarchę i wszystkich dostojników znajdujących się przy boku Leszczyńskiego. Tuż po obiedzie dojechał tamże wojewoda kijowski Józef Potocki, który opuścił swoje wojsko, stojące o 5 mil od Lwowa. Do miasta wrócił król około godziny 4 po południu i wysłał jakiś list do hetmana litewskiego Jana Kazimierza Sapiehy. Potem udał się do Karola Wapowskiego; byli tam też biskup Teodor Potocki i Adam Śmigielski, którzy pokazywali sztuczki z kartami. Kolację jadł król u biskupa Potockiego, uczestniczyli w niej również Józef Potocki, Aleksander Jan Jabłonowski, Stanisław Tarło, Adam Śmigielski i Józef Poniatowski. Król, po powrocie do swej kamienicy, grał w karty z Tarłą, Poniatowskim i Śmigielskim. Ten ostatni przegrał około 100 dukatów (1800 złp) ${ }^{72}$.

\section{Odwrót na Pomorze Szwedzkie}

W niedzielę 21 kwietnia o godzinie 7 rano król Stanisław opuścił Lwów. Zatrzymał się na popas w Janowie, nocował w Jaworowie. Następnego

\footnotetext{
71 Ibidem, s. 203-204.

72 Ibidem, s. 204-205.
} 
dnia był już z powrotem w Wysocku koło Jarosławia. Niespodziewany wyjazd monarchy ze Lwowa, w świetle ówczesnej sytuacji militarnej wojsk wiernych Leszczyńskiemu i wspierających je oddziałów szwedzkich, może wydawać się niczym nieumotywowany. Hetman wielki litewski Jan Kazimierz Sapieha po zwycięstwie pod Lachowcami wycofał się wprawdzie pod Beresteczko, ale oddziały jego przeciwnika Hrehorego Ogińskiego nie były w stanie stawiać znaczącego oporu. Siły wojewody kijowskiego Józefa Potockiego kontynuowały ofensywę w kierunku południowo-wschodnim. Ponadto 19 kwietnia 1709 do Lwowa dotarła informacja, że hetman Adam Mikołaj Sieniawski, obawiając się ataku wojsk stanisławowskich, wycofał się aż pod Kamieniec Podolski ${ }^{73}$. Z końcem kwietnia 1709 r. płk Adam Śmigielski rozpoczął zresztą oblężenie Brzeżan, twierdzy należącej do hetmana Sieniawskiego. W trakcie tych działań zbrojnych okazało się ponadto, że wojska rosyjskie przebywające na Wołyniu i Podolu są w rzeczywistości niezbyt liczne ${ }^{74}$.

Wątpliwości może budzić miejsce pobytu szwedzkiego korpusu dowodzonego przez gen. Krassowa. Według niepewnych informacji regimentarza Stanisława Krosnowskiego, jakieś regimenty szwedzkie i sam generał przebywali około połowy kwietnia 1709 r. wraz z królem Stanisławem we Lwowie, choć niemal w tym samym czasie regimentarz donosił hetmanowi Sieniawskiemu, iż Krassow z niewielkim oddziałem 400 drabantów dotarł dopiero do Wysocka koło Jarosławia ${ }^{75}$. W pamiętnikach tzw. Erazma Otwinowskiego, który znał te wydarzenia jedynie z pogłosek i relacji innych osób, jest tylko krótka wzmianka, iż Szwedzi wraz z królem Stanisławem, posuwając się bardzo powoli, „zaszli aż za Lwów”, nie atakowali jednak wojsk hetmana Adama Sieniawskiego, zajmując się głównie wyciskaniem z miejscowej ludności kontrybucji pieniężnych ${ }^{76}$. Tymczasem w relacji królewskiego sekretarza Jozafata Michała Karpia nie ma żadnych wzmianek o ówczesnym pobycie we Lwowie gen. Krassowa, ani jego oficerów. Jedyna informacja dotyczy przejścia oddziałów szwedzkich w dniach 10-11 kwietnia 1709 r. z ziemi przemyskiej w pobliże Jaworowa. Nie wiemy, czy posunęły się one dalej na wschód w kierunku Lwowa. Co więcej, Karp pisał, że rano 18 kwietnia tego roku król Stanisław wysłał ze Lwowa jakiś list do Krassowa ${ }^{77}$. Tymczasem w literaturze historycznej

73 Ibidem, s. 204.

74 T. Ciesielski, Ostatnie tryumfy bitewne, s. 259-260; A. Perłakowski, op. cit., s. 272-273.

75 A. Perłakowski, op. cit., s. 270.

${ }^{76}$ E. Otwinowski, Dzieje Polski pod panowaniem Augusta II od roku 1696-1728, Kraków 1849, s. 143-144.

77 Przy boku króla Stanisława, t. 2, s. 203 (J.M. Karp do K.S. Radziwiłła, Lwów 21 IV 1709). 
już w XIX w. pojawiła się wiadomość o przybyciu do Lwowa, w ślad za królem Stanisławem, także wojsk szwedzkich dowodzonych przez tego generała $^{78}$. Również Jan Wimmer twierdził, że już w końcu marca 1709 r. Lwów został obsadzony przez garnizon szwedzki, ale mylnie interpretował on informacje zawarte w pamiętniku Wawrzyńca Rakowskiego, gdzie wyraźnie była mowa, iż we Lwowie stanął wówczas regiment piechoty króla Stanisława, a nie Szwedzi ${ }^{79}$. Zdaniem Józefa Andrzeja Gierowskiego wojska szwedzkie nie wzięły udziału w ofensywie podjętej przez Józefa Potockiego i Adama Śmigielskiego w drugiej połowie kwietnia przeciw wojskom kwarcianym hetmana Sieniawskiego, gdyż dla gen. Krassowa ważniejsze było „wysyłanie silnych podjazdów w Krakowskie” i ściąganie stamtąd kontrybucji ${ }^{80}$. Nie można oczywiście wykluczyć, że informacje o ówczesnym pobycie Szwedów we Lwowie wynikały z faktu, iż jakiś niewielki oddział szwedzki, stanowiący eskortę króla Stanisława, rzeczywiście zajął kwatery w mieście (mogli to być zresztą drabanci, czyli gwardziści królewscy, a byli nimi przeważnie Szwedzi).

Zagadkę niespodziewanego wyjazdu króla Stanisława ze Lwowa można wyjaśnić w dwojaki sposób. Po pierwsze, jak już wspomniano, 17 kwietnia 1709 r. został wysłany ze Lwowa do hetmanowej Elżbiety Sieniawskiej królewicz Konstanty Sobieski, który należał wówczas do najbliższych przyjaciół i powierników monarchy. Zapewne była to jedna z ostatnich prób pozyskania hetmana Adama Mikołaja Sieniawskiego i nakłonienia go do przejścia z całym wojskiem na stronę Stanisława Leszczyńskiego. Król mógł przypuszczać, że hetman wobec sukcesów wojsk stanisławowskich okaże się skłonny do ustępstw. W tej sytuacji dłuższy pobyt monarchy we Lwowie nie był już konieczny. Oczekując na informacje o przystąpieniu Sieniawskiego, wycofał się do wspierających go oddziałów szwedzkich, bez ich pomocy ofensywa w głąb Ukrainy była niemożliwa. Fakt, iż gen. Krassow nie przejawiał w kwietniu 1709 r. ochoty na żadną większą akcję zaczepną, w jakiejś mierze potwierdza tę hipotezę.

Istnieje jednak możliwość, że krótka wyprawa króla Stanisława do Lwowa była jedynie jego osobistą inicjatywą i miała wyłącznie podłoże finansowe. Monarcha, mający ciągłe kłopoty materialne, liczył na uzyskanie od miasta jakiejś znacznej kwoty pieniężnej. Wydaje się, że pod tym względem podróż ta była owocna. Co prawda królewski sekretarz Jozafat

${ }^{78}$ I. Chodyniecki, op. cit., s. 269.

${ }^{79}$ J. Wimmer, op. cit., s. 338; W.F. Rakowski, Pamiętnik Wielkiej Wojny Pótnocnej, wyd. M. Nagielski, M. Wagner, Warszawa 2002, s. 111.

${ }^{80}$ J.A. Gierowski, W cieniu Ligi Pótnocnej, s. 75. 
Michał Karp nic nie wspomina o podarowaniu monarsze przez władze Lwowa pieniędzy, ale dobrze poinformowany cześnik wiski Wawrzyniec Franciszek Rakowski, dowodzący chorągwią piechoty łanowej podlegającą rozkazom hetmana Sieniawskiego, pisał w swym pamiętniku, iż regiment piechoty króla Stanisława ściągnął wówczas ze Lwowa 10 tys. talarów (60 tys. złp) kontrybucji, a miasto pożyczyło monarsze taką samą kwotę. Można przypuszczać, iż przekazanie tej „pożyczki” mogło nastąpić w sobotę 20 kwietnia 1709 r. podczas audiencji władz miejskich Lwowa u monarchy. Wiarygodność tego przekazu wzmacnia zamieszczona przez Rakowskiego informacja, że lekarz gen. Krassowa domagał się od miasta

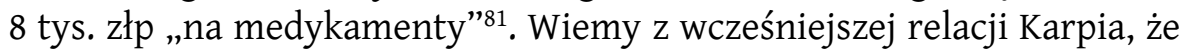
tenże lekarz dostał się swego czasu do niewoli hetmana Sieniawskiego, lecz za wstawiennictwem biskupa chełmińskiego Teodora Potockiego został w połowie marca $1709 \mathrm{r}$. wypuszczony ${ }^{82}$. Jest więc możliwe, że towarzyszył królowi Stanisławowi podczas jego wizyty we Lwowie.

W świetle informacji docierających wówczas do hetmanowej wielkiej koronnej Elżbiety Sieniawskiej, królewska wizyta we Lwowie przyniosła miastu znaczne szkody i nie przysporzyła bynajmniej monarsze popularności. W liście do męża Adama Mikołaja Sieniawskiego z 25 kwietnia 1709 r. pisała, że Leszczyński przebywał we Lwowie od piątku 12 kwietnia do niedzieli 21 kwietnia, czyli całe 10 dni. Straty były, jej zdaniem, większe niż wyrządzone podczas wzięcia miasta szturmem przez Karola XII w 1704 r. Kapucynów lwowskich (wspieranych finansowo przez Sieniawskich) wzięto w areszt pod pretekstem korespondencji z carem Piotrem I, uszkodzono kościół i klasztor Bernardynów, gdyż szukano skrzyń (z pieniędzmi?) zakopanych tam przez zmarłego podskarbiego nadwornego Atanazego Miączyńskiego, podobno je zresztą znaleziono. Sieniawska wyraźnie była oburzona postawą króla Stanisława i jego oddziałów. Informując męża, że podczas odwrotu ze Lwowa Leszczyński był atakowany przez lekkie chorągwie płk. Stefana Błędowskiego, wyraźnie żałowała, że nie wtargnęły one nieco wcześniej do Janowa, gdzie mogłyby wziąć króla do niewoli ${ }^{83}$.

Dopiero po powrocie Stanisława Leszczyńskiego do Wysocka okazało się, iż decyzja o odwrocie była słuszna. Co prawda jeszcze 5 maja $1709 \mathrm{r}$. dotarła tam wiadomość, iż płk Adam Śmigielski zdobył Brzeżany, ale już 12 maja okazało się, że w rzeczywistości po kilkudniowym oblężeniu

81 W.F. Rakowski, op. cit., s. 111.

${ }^{82}$ Przy boku króla Stanisława, t. 2, s. 176 (J.M. Karp do K.S. Radziwiłła, Machnów 14 III 1709).

${ }^{83}$ Korespondencja Elżbiety z Lubomirskich Sieniawskiej, s. 234. 
musiał się wycofać spod tej twierdzy ${ }^{84}$. Dzień wcześniej pojawiły się w Wysocku informacje, iż rosyjski feldmarszałek Henryk Goltz, który przedtem służył w armii polskiej i saskiej, wraz z korpusem liczącym około 20 tys. żołnierzy idzie na pomoc hetmanowi Sieniawskiemu. Hetman wielki litewski Jan Kazimierz Sapieha wyraźnie był zdezorientowany i przyjechał do króla Stanisława, aby naradzić się, jak ma postępować w tej sytuacji ${ }^{85} .13$ maja przyszły wprawdzie uspokajające wiadomości, że siły rosyjskie liczą tylko 10 tys. żołnierzy, a regimenty kawalerii podobno są w złym stanie, ale gen. Krassow wyraźnie przejął się tymi doniesieniami i podjął decyzję o wycofaniu swych oddziałów 16 maja do Sandomierza. Dopiero król Stanisław wytłumaczył mu, że nie ma powodu do paniki, bo Rosjanie mogą dojść w okolice Przemyśla najwcześniej za dwa tygodnie ${ }^{86}$.

Szwedzki generał zdawał sobie sprawę, że nie dysponuje wystarczającymi siłami, by przeciwstawić się liczniejszej armii rosyjskiej. Plany wycofania się za linię Wisły wynikały z informacji o rozkazach Karola XII, który polecił regimentom piechoty stojącym na Pomorzu Szwedzkim i w Poznaniu wyruszyć na pomoc gen. Krassowowi. Pierwsze wiadomości o tej decyzji dotarły do Krassowa i króla Stanisława dopiero 27 kwietnia 1709 r. Bardziej szczegółowe informacje napłynęły 2 maja. Dowódcą tych sił, liczących 8 tys. piechoty, miał być gen. Hans Isak Ridderhielm ${ }^{87}$. 13 maja już wiedziano, że w skład tego korpusu ostatecznie ma wejść pięć regimentów piechoty (razem 6 tys. żołnierzy) i dwa regimenty kawalerii (około 2 tys. ludzi), ale gen. Ridderhielm z powodu choroby na razie nie obejmie dowództwa ${ }^{88}$. W tej sytuacji gen. Krassow chciał cofnąć się w kierunku nadchodzących posiłków i dopiero po połączeniu z nimi znowu ruszyć na wschód ${ }^{89}$.

Tymczasem z doniesień hetmana litewskiego Jana Kazimierza Sapiehy, które dotarły do Wysocka 25 maja 1709 r. wynikało, że wojska rosyjskie wspomagające hetmana Adama Mikołaja Sieniawskiego są stosunkowo nieliczne i, co więcej, nie zamierzają one w najbliższym

${ }^{84}$ Przy boku króla Stanisława, t. 2, s. 211-212 i 219 (J.M. Karp do K.S. Radziwiłła, Wysocko 15 V 1709).

${ }^{85}$ Ibidem, s. 218 (J.M. Karp do K.S. Radziwiłła, Wysocko 15 V 1709); o połączeniu sił rosyjskich z wojskami hetmana Sieniawskiego zob. A. Kamiński, op. cit., s. 143.

${ }^{86}$ Przy boku króla Stanisława, t. 2, s. 219-220 (J.M. Karp do K.S. Radziwiłła, Wysocko 15 V 1709).

${ }^{87}$ Ibidem, s. 207 i 210 (J.M. Karp do K.S. Radziwiłła, Wysocko 3 V 1709).

${ }^{88}$ Ibidem, s. 220 (J.M. Karp do K.S. Radziwiłła, Wysocko 15 V 1709).

${ }^{89}$ Zwrócił na to uwagę też Peter From: „Krassow potrzebował posiłków z Pomorza [Szwedzkiego - J.D.] i chciał poczekać na ich przyjście przed rozpoczęciem dalszych operacji”, op. cit., s. 227. 
czasie podejmować działań ofensywnych. Sapieha radził więc królowi Stanisławowi, by nie myślał o odwrocie. Powtórny list z taką samą radą dotarł do monarchy dwa dni później, prawie jednocześnie doszła do Leszczyńskiego wiadomość, iż hetman Sapieha w nocy z 24 na 25 maja rozbił pod Nakwaszą (2 mile od Oleska) rajtarię Hrehorego Ogińskiego i kilka tysięcy posiłkujących go żołnierzy rosyjskich ${ }^{90}$. W rzeczywistości Sapieha, nie zdając sobie sprawy z faktycznej liczebności korpusu feldmarszałka Henryka Goltza, wyruszył 23 maja ze swego obozu, chcąc uderzyć na osłabioną po bitwie pod Lachowcami dywizję Ogińskiego. Do starcia doszło następnego dnia pod wsią Nakwasza. Początkowo przyniosło ono sukces oddziałom litewskim, które zmusiły jazdę rosyjską do wycofania się, jednak gdy do akcji wkroczyły carskie piechota i artyleria, hetman Sapieha zarządził odwrót swych sił. Rosjanie ponieśli wprawdzie duże straty, ale to oni po tej bitwie przejęli inicjatywę, a Sapieha wycofał się na Polesie, niejako otwierając wojskom rosyjskim i oddziałom hetmana Sieniawskiego drogę w kierunku Małopolski ${ }^{91}$.

Informacje o rzeczywistym wyniku bitwy pod Nakwaszą dotarły do króla Stanisława i gen. Krassowa 29 maja 1709 r. Niektóre relacje mówiły nawet o całkowitej klęsce wojsk litewskich, ale jeden z oficerów uczestniczących w tej bitwie twierdził, iż hetman Sapieha po zadaniu znacznych strat wojskom rosyjskim, gdy nadeszły główne siły feldmarszałka Goltza, wycofał się w najlepszym porządku ${ }^{92}$. Przypuszczalnie to właśnie te informacje o niepowodzeniu hetmana Sapiehy skłoniły ostatecznie gen. Krasowa do odwrotu. Część sił szwedzkich zaczęła opuszczać Jarosław już 30 maja, kierując się na Przeworsk, większość stanęła jednak w obozie pod Pełkinią, na północny zachód od Jarosławia, czekając na dalszy rozwój wydarzeń. Tam też przebywał król Stanisław ${ }^{93}$. Ostatecznie dopiero 10 czerwca 1709 r. Leszczyński w towarzystwie regimentów szwedzkich wyruszył w dalszą drogę ${ }^{94}$. Posuwano się na północny zachód przez Przeworsk, Łańcut, Rzeszów (gdzie król spotkał się 14 czerwca z Anną Wapowską $\left.{ }^{95}\right)$, Sędziszów Małopolski, Szczucin,

${ }^{90}$ Przy boku króla Stanisława, t. 2, s. 227-229 (J.M. Karp do K.S. Radziwiłła, Wysocko 26 V 1709, Jarosław 31 V 1709).

91 T. Ciesielski, Ostatnie tryumfy bitewne, s. 262-265.

${ }_{92}$ Przy boku króla Stanisława, t. 2, s. 230 (J.M. Karp do K.S. Radziwiłła, Jarosław 31 V 1709).

93 Ibidem, s. 231 (J.M. Karp do K.S. Radziwiłła, Jarosław 31 V 1709).

${ }^{94}$ Ibidem, s. 239-240 (J.M. Karp do K.S. Radziwiłła, pod Trzebowniskiem koło Rzeszowa 14 VI 1709).

95 Ibidem, s. 243 (J.M. Karp do K.S. Radziwiłła, w obozie pod Szopnicą [Sepnicą] 18 VI 1709). 
Bolesław koło Dąbrowy Tarnowskiej, docierając 30 lipca do Opatowca na lewym brzegu Wisły ${ }^{96}$.

Podczas tego przemarszu z niecierpliwością oczekiwano na informacje o zbliżaniu się szwedzkiej piechoty z Pomorza Szczecińskiego. Już 11 czerwca 1709 r. dotarła do króla Stanisława wiadomość, że szwedzkie regimenty wyruszyły 28 maja ze Szczecina, kierując się na południe ${ }^{97}$. Dalsze doniesienia nie napawały jednak optymizmem. Okazało się bowiem, że oddziały te stanęły w Wielkopolsce, oczekując na powrót z Cieplic swego dowódcy, gen. Ridderhielma, który przebywał tam na kuracji (zmarł zresztą tamże 3 sierpnia 1709) ${ }^{98} .25$ czerwca do króla Stanisława doszła informacja, że piechota szwedzka dotarła już do miasta Zduny (na wschód od Rawicza), a komendę nad nią objął płk Martin Schultz, który podobnie jak gen. Krassow nie miał doświadczenia w dowodzeniu większymi zgrupowaniami. Król optymistycznie spodziewał się, że w ciągu dwóch tygodni połączą się one $\mathrm{z}$ korpusem Krassowa ${ }^{99}$. Tymczasem z kolejnych wiadomości wynikało, że Szwedzi stanęli w Wielkopolsce na dłużej, nakładając na tamtejszą ludność ogromne kontrybucje i żądając dostaw żywności. Co prawda gen. Krassow wysyłał rozkazy przyspieszenia marszu, lecz nie przyniosło to większego skutku. Wprawdzie 11 lipca przyszła informacja, że regimenty szwedzkie wkroczyły do województwa sieradzkiego, lecz wkrótce okazało się, że także tam zajęte są one ściąganiem pieniędzy. Pułkownik Schultz tłumaczył opóźnienie marszu tym, że jego regimenty wyszły z Pomorza bez wypłaconego żołdu i musi w Wielkopolsce ściągać kontrybucje, by mieć pieniądze dla żołnierzy ${ }^{100}$.

Tymczasem 18 lipca 1709 r. do obozu gen. Krassowa i do króla Stanisława dotarły pierwsze pogłoski o bitwie pod Połtawą (8 lipca) i zwycięstwie cara Piotra ${ }^{101}$. Potem jednak napływały wykluczające się informacje i w otoczeniu Leszczyńskiego przez cały miesiąc nie dawano wiary w klęskę Karola XII. Dopiero 15 i 18 sierpnia nadeszły szczegółowe relacje potwierdzające rosyjskie zwycięstwo i ucieczkę króla szwedzkiego na terytorium tureckie ${ }^{102}$. Ponieważ wojska rosyjskie feldmarszałka

${ }^{96}$ Ibidem, s. 277 (J.M. Karp do K.S. Radziwiłła, Opatowiec 30 VII 1709).

97 Ibidem, s. 240-241 (J.M. Karp do K.S. Radziwiłła, pod Trzebowniskiem 14 VI 1709).

98 Ibidem, s. 248 (J.M. Karp do K.S. Radziwiłła, [24? VI] 1709); A. Lewenhaupt, op. cit., s. 550.

99 Przy boku króla Stanisława, t. 2, s. 251 (J.M. Karp do K.S. Radziwiłła, pod Szczucinem 30 VI 1709); A. Lewenhaupt, op. cit., s. 611.

100 Przy boku króla Stanisława, t. 2, s. 262 i 269 (J.M. Karp do K.S. Radziwiłła, pod Bolesławem 25 VII 1709).

${ }^{101}$ Ibidem, s. 265-266 (J.M. Karp do K.S. Radziwiłła, pod Bolesławem 25 VII 1709).

102 Ibidem, s. 285 i 289-290 (J.M. Karp do K.S. Radziwiłła, Opatowiec 16 i 20 VIII 1709). 
Henryka Goltza i oddziały hetmana Adama Sieniawskiego zbliżały się do Wisły, gen. Krassow i król Stanisław opuścili 21 i 22 sierpnia Opatowiec i przez Koprzywnicę oraz Opatów dotarli do Łagowa, miasteczka należącego do biskupów krakowskich, położonego u stóp opactwa Świętego Krzyża na Łysej Górze. Tam też 2 września 1709 r. doszło wreszcie do spotkania szwedzkich regimentów płk. Schultza z oddziałami gen. Krassowa. Oczywiście nie było już mowy o spieszeniu z odsieczą Karolowi XII. Postanowiono natomiast, po połączeniu się z siłami hetmana litewskiego Jana Kazimierza Sapiehy, uderzyć na wojsko saskie, które właśnie wraz z Augustem II wkraczało do Polski ${ }^{103}$. Generał Krassow ostatecznie nie zdecydował się na ten krok. Umiejętnie manewrując, przeprowadził swoje oddziały na teren Pomorza Szwedzkiego, towarzyszył mu król Stanisław i nieliczni pozostali przy nim jego stronnicy. Krassowa spotkały później zarzuty, że nie rozbił stosunkowo niewielkich sił saskich. Na jego obronę można jednak powiedzieć, iż mógł obawiać się, że z tyłu uderzą na niego zbliżające się wojska rosyjskie. Nie mógł przewidzieć, że feldmarszałek Goltz także nie będzie się spieszył do starcia i zwolni tempo swego marszu. Car Piotr I zresztą zdymisjonował go za to, że pozwolił wymknąć się Krassowowi ${ }^{104}$.

Analizując wyprawę króla Stanisława z Malborka do Lwowa, a potem odwrót aż do szwedzkiego Szczecina, należy stwierdzić, że zadanie postawione przez Karola XII gen. Krassowowi było praktycznie niewykonalne. Dysponował on zbyt szczupłymi siłami, by rozbić wojska antystanisławowskiej konfederacji sandomierskiej, a następnie iść na pomoc szwedzkiemu monarsze w głąb Rosji, zwłaszcza że na jego drodze stanąłby silny garnizon rosyjski w Kijowie. Rozkazy wzmocnienia korpusu Krassowa o regimenty piechoty z Pomorza Szwedzkiego zostały wydane stanowczo zbyt późno, a ponadto upłynęło wiele czasu, zanim dotarły one do prowincji pomorskiej. Generał Krassow przypuszczalnie już po klęsce wojsk stanisławowskich Józefa Potockiego pod Koniecpolem (21 XI 1708) zorientował się, że nie będzie mógł liczyć na skuteczne wsparcie ze strony oddziałów wiernych królowi Stanisławowi. Dlatego też wyraźnie opóźniał marsz swego korpusu na południowy wschód, nie prowadząc praktycznie żadnych szerszych akcji ofensywnych. Wydaje się zresztą, jak to już wspomniano, że jego kompetencje bardziej odpowiadały stanowisku kwatermistrza niż liniowego dowódcy większego zgrupowania. Nie zachęcał go do bardziej zdecydowanych akcji i Stanisław Leszczyński,

103 Ibidem, s. 298-300 (J.M. Karp do K.S. Radziwiłła, Kozłów 8 IX 1709).

104 G.A. Nordberg, op. cit., s. 357; K. Jarochowski, op. cit., s. 257-261; J.A. Gierowski, W cieniu Ligi Pótnocnej, s. 89-91. 
który liczył raczej na pokojowe zabiegi, zmierzające do przeciągnięcia na swoją stronę konfederatów sandomierskich, a przynajmniej wojska koronnego podporządkowanego hetmanowi Adamowi Mikołajowi Sieniawskiemu, lub na rozbicie sił konfederacji sandomierskiej przez zwycięskiego Karola XII. Również płk Martin Schultz, dowodzący posiłkami maszerującymi z Pomorza Szwedzkiego, który zajął na dłuższy czas leża w województwach wielkopolskich i ściągał stamtąd pieniądze i żywność, nie przejawiał najmniejszej ochoty na szybkie połączenie się z gen. Krassowem. Można stąd wyciągnąć wniosek, iż niektórzy wyżsi oficerowie szwedzcy, realnie oceniając istniejącą sytuację (mieli zbyt mało wojska, by zmusić przeciwników króla Stanisława do kapitulacji), nie zamierzali osobiście angażować się w kampanię rosyjską, bezpiecznie czekając $\mathrm{w}$ Polsce na ostateczny wynik batalii.

\section{Streszczenie}

W dotychczasowej literaturze historycznej prawie nie ma informacji o pobycie we Lwowie króla Stanisława Leszczyńskiego w kwietniu 1709 r. Na podstawie listów królewskiego sekretarza Jozafata Michała Karpia udało się przedstawić podróż monarchy z Malborka do Lwowa, a następnie okoliczności jego odwrotu aż do szwedzkiego wówczas Szczecina. Król Szwecji Karol XII, wyprawiając się latem 1708 r. do Rosji, zostawił w Polsce króla Stanisława. Miał on, wraz z towarzyszącym mu korpusem szwedzkim, zmusić do kapitulacji swoich przeciwników, dawnych stronników króla Augusta II Wettina, i ruszyć z pomocą Karolowi XII na Ukrainę. Zadanie to nie zostało wykonane, gdyż wojska szwedzkie pozostawione w Polsce były zbyt nieliczne, a poza tym ich dowódca, gen. Ernst Detlof Krassow (Krassau, Krassaw), nie przejawiał specjalnej ochoty do przeprowadzania akcji ofensywnych. Królowi Stanisławowi udało się wprawdzie dotrzeć do Lwowa, ale dalszy marsz na wschód wobec pojawienia się na Wołyniu i Podolu wojsk rosyjskich, okazał się niemożliwy. Klęska Karola XII w bitwie pod Połtawą oznaczała wycofanie się Stanisława Leszczyńskiego z Polski, do której powrócił August II.

\section{Lviv's Expedition of King Stanisław Leszczyński in 1709 (Was He Going to Help Charles XII in Ukraine?)}

There is almost no information in the literature on the subject of King Stanisław Leszczyński's visit to Lviv in April 1709. The letters written by royal secretary Jozafat Michał Karp made it possible to reconstruct the journey of the king from Malbork to Lviv, and then the circumstances of his retreat up to Swedish at that time Szczecin (Stettin). While going to Russia in the summer of 1708, King Charles XII of Sweden left King Stanisław in Poland. The latter, together with accompanying 
Swedish corps, had to force his opponents, the former supporters of King Augustus II Wettin, to surrender, and then he was expected to go to Ukraine to support Charles XII. The task was not fulfilled for the Swedish troops left in Poland were too small, and their commander, Gen. Ernst Detlof Krassow (Krassaw, Krassau), was not eager to conduct offensive actions. Even though King Stanisław managed to reach Lviv, the further march eastwards turned out to be impossible after the Russian forces entered Volhynia and Podolia. The defeat of King Charles XII in the Battle of Poltava meant that King Stanisław Leszczyński had to leave Poland, making place for the return of King Augustus II.

Translated by Grażyna Waluga

\section{Bibliografia}

Achremczyk Stanisław, Stanisław Leszczyński w Prusach Królewskich i w Prusach Ksiażęcych, „Komunikaty Mazursko-Warmińskie” 2006, 1, s. 69-87.

Chodyniecki Ignacy, Historja stołecznego Królestw Galicyi i Lodomerii miasta Lwowa, Wyd. Karol Wild, Lwów 1865 [wyd. 2].

Ciesielski Tomasz, Kariera wojskowa Jana Kazimierza Sapiehy, w: Wielkie rody dawnej Rzeczypospolitej XVI-XIX wieku, t. 1: Sapiehowie, red. Tomasz Ciesielski, Mariusz Sawicki, Wydawnictwo Uniwersytetu Opolskiego, Opole 2018, s. 333-371.

Ciesielski Tomasz, Ostatnie tryumfy bitewne oręża Wielkiego Księstwa Litewskiego - bitwy pod Lachowcami i Nakwasza, w: Vaennyâ tryumfy epohi Vâlikaga Knâstva Litoŭskaga. Zbornik navukovyh artykulaŭ, red. M.N. Gal'pârovič, Mir 2017, s. 249-270.

Cieślak Edmund, Stanisław Leszczyński, Ossolineum, Wrocław 1994.

Dygdała Jerzy, Leszczyński w Saksonii, „Mówią Wieki” 2008, 11, s. 41-44.

Dygdała Jerzy, Wizyta króla Stanisława Leszczyńskiego $w$ Wilnie $w$ dniach 22-29 marca 1708 roku, w: Inter Regnum et Ducatum. Studia ofiarowane Profesorowi Janowi Tegowskiemu w siedemdziesiąta rocznice urodzin, red. Piotr Guzowski, Marzena Liedke, Krzysztof Boroda, Instytut Badań nad Dziedzictwem Kulturowym Europy, Białystok 2018, s. 119-131.

Dygdała Jerzy, Z Torunia do Wilna podróż króla Stanisława zimą 1708 roku, ZH 82, 2017, 2, s. 85-99.

Feldman Józef, Polska w dobie wielkiej wojny północnej 1704-1709, PAU, Kraków 1925. Feldman Józef, Stanisław Leszczyński, PIW, Warszawa 1984.

From Peter, Klęska pod Połtawa. Kampania Karola XII w Rosji w latach 1707-1709, Inforteditions, Zabrze 2010.

Gierowski Józef Andrzej, Nieznany list miłosny Stanisława Leszczyńskiego do Marianny Denhoffowej, w: Ludzie, kontakty, kultura XVI-XVIII w. Prace ofiarowane Profesor Marii Boguckiej, red. Jerzy Kowecki, Janusz Tazbir, Semper, Warszawa 1997, s. 167-169. Gierowski Józef Andrzej, Stanisław Leszczyński w latach 1707-1709 w opiniach dyplomatów francuskich, „Acta Universitatis Wratislaviensis. Historia” 36, 1981, s. 155-164. Gierowski Józef Andrzej, W cieniu Ligi Pótnocnej, Ossolineum, Wrocław 1971.

Grauers Sven, Stosunek szwedzkich i polskich sił zbrojnych podczas wielkiej wojny północnej, „Studia i Materiały do Historii Wojskowości” 20, 1976, s. 122-151. 
Herlitz Nils, Den polska frågan 1708-1709, „Karolinska Forbundets Årsbok” 1914, s. $151-173$.

Hultman Johan D., O panowaniu Karola XII króla Szwecji, wyd. i przetłum. Wojciech Krawczuk, Eternum, Kraków 2015.

Jarochowski Kazimierz, Stanisław Leszczyński po Pułtawie, w: idem, Opowiadania i studia historyczne, serya nowa, C.F. Piotrowski i Sp., Poznań 1884, s. 225-273.

Jaworski Franciszek, Królowie polscy we Lwowie, nakł. Towarzystwa Miłośników Przeszłości Lwowa, Księgarnia Gubrynowicza i Syna, Lwów 1912.

Józefowicz Jan Tomasz, Lwów utrapiony in anno 1704 albo Dyjaryjusz wziętego Lwowa przez króla szwedzkiego Karola XII die 6 mensis Septembris anno 1704, wyd. Piotr Borek, Collegium Columbinum, Kraków 2003.

Kamiński Andrzej, Konfederacja sandomierska wobec Rosji w okresie poaltransztadzkim 1706-1709, Ossolineum, PAN, Wrocław 1969.

Karpowicz Mariusz, Jerzy Eleuter Siemiginowski, malarz polskiego baroku, Ossolineum, Wrocław-Warszawa 1974.

Korespondencja Elżbiety z Lubomirskich Sieniawskiej, kasztelanowej krakowskiej, t. 1: Z serca kochajacca żona i uniżona sługa. Listy Elżbiety z Lubomirskich Sieniawskiej do męża Adama Mikołaja Sieniawskiego z lat 1688-1726, wyd. Bożena Popiołek, Urszula Kicińska, Agnieszka Słaby, DiG, La Rama, Warszawa-Bellerive-sur-Allier 2016.

Krzemiński Jan Michał, Od Sasa do Sasa. Królewskie popasy w Malborku, z kroniki malborskiej rezydencji jezuitów, „Rocznik Gdański” 45, 1985, 1, s. 173-193.

Lewenhaupt Adam, Karl XII:s officerare. Biografiska anteckningar, t. 2, P.A. Norstedt \& Söners förlag, Stockholm 1921.

Liljegren Bengt, Karol XII, Katmar, Gdańsk 2015.

Nordberg Georges A., Histoire de Charles XII, roi de Suede, La Haye 1748.

Nowiny z r. 1706, 1707, 1708, 1709, wyd. Sadok Barącz, w: idem, Pamiętnik dziejów polskich. $Z$ aktów urzędowych lwowskich i z rękopisów, nakł. Wojciecha Manieckiego, Lwów 1855.

[tzw. Otwinowski Erazm], Dzieje Polski pod panowaniem Augusta II od roku 1696-1728, nakł. i dr. Józefa Czecha, Kraków 1849.

Pabich Łukasz, Bitwa pod Koniecpolem 21 listopada 1708, Inforteditions, Zabrze-Tarnowskie Góry 2014.

Perłakowski Adam, Plotki, sprzeczne informacje i gra pozorów. Działalność Stanisława Krosnowskiego, regimentarza Adama Mikołaja Sieniawskiego, hetmana wielkiego koronnego w latach 1707-1709, w: Historia na źródłach oparta. Studia ofiarowane Profesorowi Tadeuszowi Srogoszowi w 65. rocznice urodzin, red. Andrzej Stroynowski, Wydawnictwo im. S. Podobińskiego Akademii im. Jana Długosza, Częstochowa 2017, s. 259-278.

Popiołek Bożena, Lwów w czasach Augusta II, w: Lwów. Miasto, społeczeństwo, kultura. Studia z dziejów Lwowa, t. 4, red. Kazimierz Karolczak, Wydaw. Naukowe Akademii Pedagogicznej, Kraków 2002, s. 93-104.

Przy boku króla Stanisława Leszczyńskiego (1706-1709), t. 1: Wyprawy do Saksonii i Litwy w latach 1706-1708. Listy królewskich sekretarzy Samuela Kazimierza Szwykowskiego i Jozafata Michała Karpia oraz fragmenty z gazet pisanych $i$ diariuszy, wyd. Jerzy Dygdała, IH PAN, Warszawa 2018; t. 2: W wędrówkach po Polsce między Gdańskiem a Lwowem w latach 1708-1709. Listy królewskiego sekretarza Jozafata Michała 
Karpia oraz fragmenty z gazet pisanych $i$ diariuszy, wyd. Jerzy Dygdała, IH PAN, Warszawa 2019.

Rakowski Wawrzyniec Franciszek, Pamiętnik Wielkiej Wojny Północnej, wyd. Mirosław Nagielski, Marek Wagner, DiG, Warszawa 2002.

Stanisław Leszczyński. Król Polski księciem Lotaryngii. Wystawa w Zamku Królewskim w Warszawie 25 kwietnia - 10 lipca 2005 roku, red. katalogu Zofia Jurkowlaniec, Arx Regia, Warszawa 2005.

Strobach Berndt, Der Hofjude Berend Lehmann, de Gruyter, Berlin-Boston 2018.

Szydelski Stefan, Konstanty Zieliński arcybiskup lwowski, nakł. Akademii Umiejętności, Kraków 1910.

Widacka Hanna, Z króla książę. Stanisław Leszczyński w grafice XVIII wieku ze zbiorów polskich i francuskich, Biblioteka Narodowa, Warszawa 2006.

Wimmer Jan, Wojsko Rzeczypospolitej w dobie wojny pótnocnej (1700-1717), Wydawnictwo MON, Warszawa 1956.

Biogram: Jerzy Dygdała - prof. dr hab. w Instytucie Historii PAN (Zakład Historii Pomorza w Toruniu). Prowadzi prace badawcze nad historią polityczną szlacheckiej Rzeczypospolitej (okres wielkiej wojny północnej, wojny sukcesyjnej polskiej z lat 1733-1736, początków panowania Stanisława Augusta Poniatowskiego) oraz historią społeczną i kultury materialnej XVIII w. Edytor źródeł historycznych (lustracje dóbr królewskich, gazety pisane, korespondencja); kontakt: jdygdala@ihpan.edu.pl. 